DOT/FAA/AM-11/4

Office of Aerospace Medicine

Washington, DC 20591

\title{
U.S. Airline Transport Pilot International Flight Language Experiences, Report 6: Native English-Speaking Controllers Communicating With Non-Native English-Speaking Pilots
}

O. Veronika Prinzo

Civil Aerospace Medical Institute

Federal Aviation Administration

Oklahoma City, OK 73125

Alan Campbell

Johns Creek, GA 30022

Alfred M. Hendrix

Ruby Hendrix

HCS Consulting Services

Roswell, NM 88201

March 2011

Final Report 


\section{NOTICE}

This document is disseminated under the sponsorship of the U.S. Department of Transportation in the interest of information exchange. The United States Government assumes no liability for the contents thereof.

This publication and all Office of Aerospace Medicine technical reports are available in full-text from the Civil Aerospace Medical Institute's publications Web site: www.faa.gov/library/reports/medical/oamtechreports 
Technical Report Documentation Page

\begin{tabular}{|c|c|c|c|c|}
\hline \multicolumn{3}{|l|}{$\begin{array}{l}\text { 1. Report No. } \\
\text { DOT/FAA/AM-11/4 }\end{array}$} & \multicolumn{2}{|c|}{ 3. Recipient's Catalog No. } \\
\hline \multirow{3}{*}{\multicolumn{3}{|c|}{$\begin{array}{l}\text { 4. Title and Subtitle } \\
\text { U.S. Airline Transport Pilot International Flight Language Experiences, } \\
\text { Report 6: Native English-Speaking Controllers Communicating With Non- } \\
\text { Native English-Speaking Pilots }\end{array}$}} & \multirow{3}{*}{\multicolumn{2}{|c|}{$\begin{array}{l}\text { 5. Report Date } \\
\text { March } 2011\end{array}$}} \\
\hline & & & & \\
\hline & & & & \\
\hline \multicolumn{3}{|c|}{$\begin{array}{l}\text { 7. Author(s) } \\
\text { Prinzo OV, }{ }^{1} \text { Campbell A, }{ }^{2} \text { Hendrix } A,{ }^{3} \text { Hendrix }{ }^{3}\end{array}$} & \multicolumn{2}{|c|}{ 8. Performing Organization Report No. } \\
\hline \multirow{3}{*}{$\begin{array}{l}\text { 9. Performing Organization Name a } \\
{ }^{1} \text { FAA CAMI } \\
\text { P.O. Box } 25082 \\
\text { Oklahoma City, OK } 73125\end{array}$} & \multirow{3}{*}{$\begin{array}{l}\text { and Address } \\
\text { Capt. Alan Campbell } \\
\text { Johns Creek, GA } 30022\end{array}$} & & \multirow{2}{*}{\multicolumn{2}{|c|}{ 10. Work Unit No. (TRAIS) }} \\
\hline & & $\begin{array}{l}{ }^{3} \mathrm{HCS} \text { Consulting } \\
\text { Services }\end{array}$ & & \\
\hline & & & \multicolumn{2}{|c|}{ 11. Contract or Grant No. } \\
\hline \multirow{2}{*}{\multicolumn{3}{|c|}{$\begin{array}{l}\text { 12. Sponsoring Agency name and Address } \\
\text { Office of Aerospace Medicine } \\
\text { Federal Aviation Administration } \\
800 \text { Independence Ave., S.W. } \\
\text { Washington, DC } 20591\end{array}$}} & \multicolumn{2}{|c|}{ 13. Type of Report and Period Covered } \\
\hline & & & \multicolumn{2}{|c|}{ 14. Sponsoring Agency Code } \\
\hline \multicolumn{5}{|c|}{$\begin{array}{l}\text { 15. Supplemental Notes } \\
\text { This work was performed under Task AM-B-06-HRR- } 516 .\end{array}$} \\
\hline \multicolumn{5}{|c|}{$\begin{array}{l}\text { 16. Abstract: } \\
\text { In 1998, the International Civil Aviation Organization (ICAO) took a heightened interest in the role of language } \\
\text { in airline accidents. Member states agreed to take steps to ensure air traffic control personnel and flight crews } \\
\text { involved in flight operations where the use of the English language is required were proficient in conducting and } \\
\text { comprehending radiotelephony communications in English. Since then, ICAO developed its English language } \\
\text { requirements and urged its members to document their English Language Proficiency (ELP) test implementation } \\
\text { plans by March 8, 2008. This report is a compilation of written responses and comments by a group of } 48 \text { U.S. } \\
\text { pilots of their difficulties in international operations. There were } 12 \text { international U.S. pilots from American, } \\
\text { Continental, Delta, and United Airlines. In this report, the pilots' responses to questions } 54-59 \text { and their } \\
\text { comments from discussions of those questions with } 2 \text { interviewers are presented as a compiled narrative. We } \\
\text { derived } 5 \text { recommendations from these interviews. (1) Research is needed to determine the optimal speech rate for } \\
\text { ATC messages. (2) ATC messages must be delivered using standard ICAO terms and phraseology. (3) Graphic and } \\
\text { text representations of taxi clearances, route clearances, and route modifications should be made available to pilots } \\
\text { on the flight deck as stand-alone messages. (4) Research is needed to identify how controllers communicate } \\
\text { nonstandard situations (e.g., maneuvering around thunderstorms, traffic conflicts, delays). (5) Research is needed } \\
\text { to determine the extent to which the absence of party-line information has on situational awareness and safety } \\
\text { prior to takeoff and landing as pilots attempt to discern the intentions (and potential threat) of other pilots } \\
\text { (especially those less proficient in English). }\end{array}$} \\
\hline \multicolumn{2}{|c|}{$\begin{array}{l}\text { 17. Key Words } \\
\text { Communications, ATC Communication, } \\
\text { Air Traffic Control }\end{array}$} & \multicolumn{3}{|c|}{$\begin{array}{l}\text { 18. Distribution Statement } \\
\text { Document is available to the public through the Defense } \\
\text { Technical Information Center, Ft. Belvoir, VA 22060; and the } \\
\text { National Technical Information Service, Springfield, VA } 22161\end{array}$} \\
\hline $\begin{array}{l}\text { 19. Security Classif. (of this report) } \\
\text { Unclassified }\end{array}$ & \multicolumn{2}{|c|}{$\begin{array}{c}\text { 20. Security Classif. (of this page) } \\
\text { Unclassified }\end{array}$} & $\begin{array}{c}\text { 21. No. of Pages } \\
32\end{array}$ & 22. Price \\
\hline
\end{tabular}

Form DOT F 1700.7 (8-72)

Reproduction of completed page authorized 



\section{ACKNOWLEDGMENTS}

This research was sponsored by the Federal Aviation Administration Flight Technologies and Procedures Branch under the direction of William Adams (AFS-430), and the findings were provided to the Data Com Human Factors Working Group. It was conducted under the Flight Deck Program Directive/Level of Effort Agreement between the Human Factors Research and Engineering Group (AJP-61) at FAA Headquarters and the Civil Aerospace Medical Institute's Aerospace Human Factors Division (AAM-500).

We thank all the people at American, Continental, Delta, and United Airlines who were instrumental in the success of this project - especially the 48 U.S. pilots who participated in the interviews. Among these pilots were several who participated in the discussions either shortly after returning from international flights, left immediately after the interview to be part of international flight crews, or deadheaded to the company office from other states. These pilots exhibited passion for aviation safety and knew the importance their knowledge and expertise held in international flight operations. We cannot thank them enough.

We also thank Captain (retired) Terry Hanson and Mr. Graham Elliott (AMA-800) for their helpful comments and items for inclusion in the interview questions.

Finally, we thank the staff at Xyant Technologies for transcribing the many hours of voice tapes and written responses into Excel $^{\odot}$ spreadsheets. 



\section{CONTENTS}

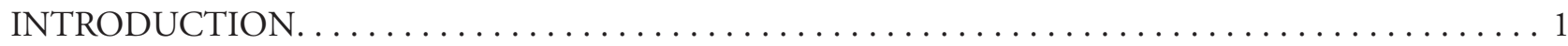

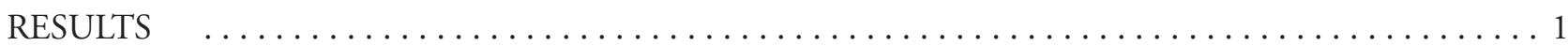

Section 8: Native English-Speaking Controllers Communicating With Non-Native English-Speaking

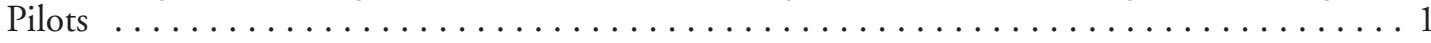

Q54. How would you characterize voice communications between international native Englishspeaking controllers and non-native English-speaking pilots?. . . . . . . . . . . . 2

Q54a. When you hear international non-native English-speaking pilots, what tells you whether they

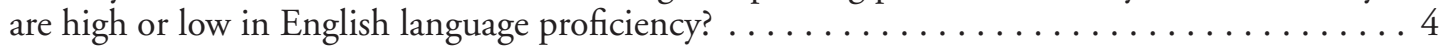

Q54b. With regard to communication tasks, what do you do when a non-native English-speaking pilot and you are on the same flight path and you suspect that pilot is low in English language

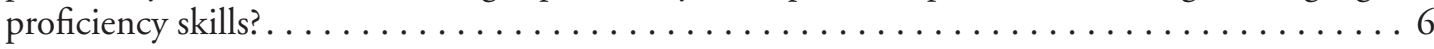

Q55. How might non-native English-speaking pilots' communications with international native English-speaking controllers differ from that of pilots and controllers who speak English?.... . 9

Q56. During a typical international flight, about how much time do non-native English-speaking pilots and international native English-speaking controllers spend talking as compared with pilots and controllers who speak English? . . . . . . . . . . . . . . . . . 12

Q57. Do international native English-speaking controllers have to communicate differently with non-native English-speaking pilots than with native English-speaking pilots? . . . . . . . 14

Q58. Describe how your situational awareness is affected when you suspect that non-native Englishspeaking pilots are experiencing difficulty understanding international English-speaking

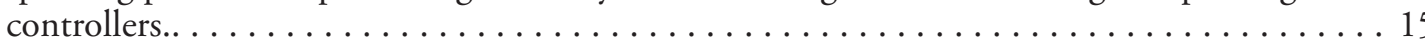

Q58a. When is your situation awareness most affected by language difficulties between non-native

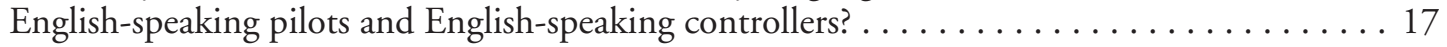

Q59. What do you do to compensate for any reduction in situational awareness?........ 18

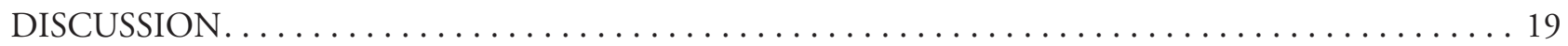

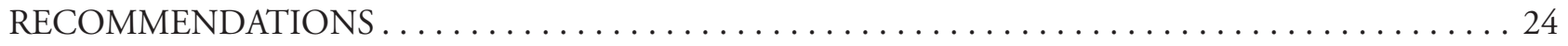

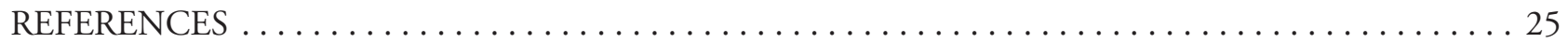





\section{EXECUTIVE SUMMARY}

This is the sixth report that presents the findings from in-depth interviews with pilots who fly internationally for major U.S. air carriers. The first series of reports are from small focus-group discussions with 48 U.S. pilots. A second series used the same format and questions with pilots flying internationally for Aeroflot, Alitalia, China Air, and LAN Chile airlines.

English language proficiency is a safety concern as noted by the International Civil Aviation Organization (ICAO, 2004). Given that international flight operations are increasing, it is important to know more about the language experiences U.S. pilots encounter when flying into countries where English may or may not be the local or national language among their radio operators, air traffic controllers, and pilots.

Several major U.S. airline companies were asked to solicit volunteers from among their international pilots to serve as paid subject matter experts in a structured interview constructed to assess the language difficulties they encounter during international flights. There were 12 pilots representing American, Continental, Delta, and United Airlines, for a total of 48 airline transport pilots (ATPs). These pilots were assumed to be representative of typical U.S. airline pilots flying internationally as to English language proficiency, familiarity with ICAO and aviation procedures, terminology, and standard air traffic phraseology. We limited the size of each interview to include no more than four pilots. Morning and afternoon sessions took place over several days at each company's preferred location.

The structured interview was divided into $10 \mathrm{sec}-$ tions: (1) Background Information, (2) Pre-Flight Preparation, (3) Air Traffic Control (ATC) Procedures, (4) Word Meaning and Pronunciation, (5) Language Experiences in Non-Native English-Speaking Airspace/ Airports, (6) Non-Native English-Speaking Controllers Communicating With Native English-Speaking Pilots,

(7) Language Experiences in Native English-Speaking Airspace/Airports, (8) Native English-Speaking Controllers Communicating With Non-Native EnglishSpeaking Pilots, (9) Communication Problems, and (10) Technological Intervention. A copy of the interview questions appears in the first report (Prinzo \& Campbell, 2008).
This report continues with the U.S. pilots' responses to questions found in Section 8. It focuses on the English language proficiency of non-native English-speaking pilots and how well they communicated with controllers who are native speakers of English. For example, U.S. controllers speak in English to all pilots, regardless of their country of origin. It is common for U.S. pilots to hear non-native English-speaking pilots communicate in English to controllers when they are outside of their country/state during international flights. The questions were designed to expose how these communication exchanges affect safety, the communication process, and situational awareness.

The pilots' answers to the questions and discussions during the interviews were their perceptions of the situations they encountered. Many stories were anecdotal, and some were relayed in third person. The analyses of those discussions and written responses are summarized and presented as if from one pilot's diary containing a compendium of flight experiences. This was done to preserve the richness and integrity of the information given during the interviews.

The pilots' responses were compiled into seven universal issues:

1. All speakers need to slow down their speech rate and speak with clarity. Extra time may be needed to decode and process a message from a non-native speaker of English (or English dialect).

2. Controllers need to develop greater patience with non-native English-speaking pilots. Once international pilots reach their destinations, they are tired and may need extra time to process a message.

3. ATC instructions can be incongruent with pilot expectations. Expectations develop from pilot experience and generally facilitate their performances. When pilot expectations are not met, uncertainty develops and communication can become labored.

4. A pilot's lack of familiarity with a country's procedures and phraseology slows down the ATC system. Pilots who are not familiar with an area (or airport) may be given a complex list of procedures and actions to follow. If nonroutine events occur due to weather, traffic, or an unforeseen event, these pilots may be at a loss as to what is being said and what they are to do. This can slow down traffic flow, add to problems, and make language barriers apparent. 
5. Countries that do not adhere to ICAO standard phraseology and terminology contribute to the communication problems that occur between that country's controllers and foreign pilots. When different phraseology exists for the same procedures, pilots must learn to develop cognitive mapping strategies to connect one set of words/phrases with that of another set.

6. The failure to communicate can distract other pilots in the area from performing their own tasks. When pilots hear other pilots on the radio having difficulty communicating with a controller, they divert attention away from their own tasks to determine whether there is a potential threat to their own flight. Ironically, this may lead to a safety problem.

7. The failure to develop a common ground of understanding is a continuing risk to flight safety. Pilots and controllers who have difficulty communicating because of language barriers create safety risks.

Finally, we present five recommendations derived from the pilots' responses to the interview questions and discussions. They are:

1. Research is needed to determine the optimal speech rate for delivery of ATC messages. If the receiver cannot adjust mechanically the speaking rate of an incoming message, then an agreed-upon rate of speech must be developed for delivery to less proficient non-native English speakers.
2. ATC messages must be delivered using standard ICAO terms and phraseology. The air traffic controller, Datalink communications system, and pilot must be in agreement as to what messages are in the data dictionary and how each message will be used to convey instructions, clearances, reports, and requests.

3. Graphic and text representations of taxi clearances, route clearances, and route modifications should be made available to pilots on the flight deck as standalone messages.

4. Research is needed to identify how controllers and pilots communicate nonstandard situations (e.g., thunderstorms, traffic conflicts, delays) to each other. New phraseology may be needed in lieu of the workaround practices currently in use. Pilots unfamiliar with the local jargon and slang are at a disadvantage and may misinterpret these conversations.

5. The absence of party-line communications can distract pilots prior to takeoff and landing as they attempt to discern the intentions (and potential threat) of other pilots (especially those less proficient in English). Research is needed to determine whether providing pilots with alternative representations of party-line information has safety benefits. 


\title{
United States Airline Transport Pilot International Flight language Experiences, Report 6: Native English-Speaking Controllers Communicating With Non-Native English-Speaking Pilots
}

\author{
To communicate effectively, you must think like your audience. You must understand the baggage they bring to any \\ situation and not just appreciate their perspective on the world but adopt it as your own, even if only momentarily. \\ - Michael Maslansky (2010) \\ Communications and research strategist
}

\section{INTRODUCTION}

This is the sixth in a series of reports derived from the responses made by 48 U.S. pilots about their international flight experiences during structured, small focus group interviews. It begins with question 54 and ends with question 59. Its focus is on how well non-native English-speaking pilots communicate in English with native English- speaking controllers. It is common for U.S. pilots to hear non-native English-speaking pilots communicate in English to controllers during their international flights. We wanted them to think about these communication exchanges heard over the party line. The first five reports present other aspects of their language and communication experiences.

The first report (Prinzo \& Campbell, 2008) analyzed the first three sections of the structured interview: 1) Background Information related to the recency of international flight experiences among the pilot-participants, 2) General/Preflight Preparation, and 3) Air Traffic Control (ATC) Procedures. It covered the U.S. pilots' responses and discussions of questions 1-23.

The second report (Prinzo, Campbell, Hendrix, \& Hendrix, 2010a) continued with U.S. pilots' flight experiences when word meanings and pronunciation became barriers to efficient and effective communication. It covered the pilots' responses and discussions to questions 24-30 in Section 4.

The third report (Prinzo, Campbell, Hendrix, \& Hendrix, 2010b) involved pilots' responses and discussions of questions 31-38 found in Section 5. It addressed their language experiences in non-native English-speaking airspace and airports. The fourth report (Prinzo, Campbell, Hendrix, \& Hendrix, 2010c) focused on the pilots' language experiences with controllers who spoke English as a foreign language and ended with question 45 . The pilots' responses to the questions in the fifth report differ from those in the third report only in terms of location; that is, the third report probed their language experiences in non-native English-speaking airspace and airports while the fifth examined their language experiences in native English-speaking airspace and airports (Prinzo, Campbell, Hendrix, \& Hendrix, 2010d).
In the current report, the focus is on pilots' experiences hearing native English-speaking controllers communicating with non-native English-speaking pilots. As with the other reports in this series, the pilots' responses were combined, condensed, and edited to remove redundancies and improve readability.

Each report was presented from the perspective of a hypothetical, albeit typical pilot with an airline transport pilot (ATP) certificate. At various times during the interviews, one or more of the pilots might be asked for additional information, or to clarify some point during the discussions. In most cases, the question was asked of an individual pilot; but there were times when all the pilots in a group were asked and it is duly notated in the text.

At the time the interviews were conducted, a reoccurring discussion point was on the difference between the U.S. and ICAO phraseologies. The most notable difference was the U.S. instruction position and hold and ICAO's line up and wait. Since then, the Federal Aviation Administration's (FAA's) Air Traffic Organization Terminal Services conducted a safety analysis and determined that adopting the phrase line up and wait will eliminate confusion, particularly among international pilots, and further decrease the risk of runway incursions. The change became effective on September 30, 2010.

\section{RESULTS}

\section{Section 8: Native English-Speaking Controllers Communicating With Non-Native English- Speaking Pilots}

The pilots' written and oral responses to questions in this section of the interview focused on English language proficiency of non-native English-speaking pilots and how well they communicate with controllers who are native speakers of English. For example, controllers in the U.S., U.K., New Zealand, and other native Englishspeaking countries use English when communicating with pilots regardless of the pilots' countries of origin. The respondents were to consider how these communication exchanges affect safety, the communication process, and situational awareness. 
Forty-eight ATP pilots responded to the questions and reported English as their primary language, having learned it informally at home. Approximately 60\% reported they neither spoke nor understood languages other than English. Many of the remaining U.S. pilots indicated they spoke/understood some French, Spanish, or both. In addition to Spanish, one pilot spoke/understood German, and another spoke/understood Spanish, French, and Portuguese. The pilots had made 77 flights to 32 different countries-14 countries were flown to once each while six flights were made to Chile. All continents except Antarctica are represented.

\section{How would you characterize voice communications between international native English-speaking con- trollers and non-native English-speaking pilots?}

Table 1 shows that one respondent characterized voice communications as "excellent," and one selected multiple responses but provided no explanation. The pilot who selected "excellent" said that most of the foreign carriers he hears in U.S. airspace seem to understand English quite well. Another $46 \%$ thought voice communications was "very good." The remaining 50\% indicated that it either "could use some changes" (29\%) or was "not good enough for extreme conditions" (21\%) such as an emergency or avoiding weather. None of the pilots reported "extremely poor" communications between non-native Englishspeaking pilots and native English-speaking controllers.

\section{Very Good in Most Respects Explanation}

Of the 22 respondents who circled "Very good in most respects," 15 discussed their selection during the small focus groups. Their discussions centered on five issues.
Failure to Communicate Can Lead to Frustration

It's been my experience that controllers in New York speak way too fast and often get short with [non-native English-speaking pilots]. I can tell right away whether the pilot's getting it or not from the time lag after the controller has given three or four instructions at once and the presence of a big pause before he reads it back.

I don't think many controllers have a clue about the level of stress they put the non-native Englishspeaking pilots under; I know because I've been on the other side of the equation [flying into non-native English airspace]. We are worn out from flying all night and are feeling the stress of too rapid a communication rate, use of slang, nonstandard ICAO terms (or no ICAO terms to begin with), and having to deal with all that.

\section{Proficiency Matters}

I've found that if the pilots are high in English proficiency, their conversations are almost normal, and the order of their words is correct. Many of these non-native English-speaking pilots are used to speaking English. In an hour's flight, they will transition over three or four different European countries and will speak English with many controllers who are not native English speakers.

Still, there are times when many of their exchanges require repetition and a slower speech rate to confirm proper understanding and communications. Of course, there are occasional circumstances where their level of proficiency would be extremely poor or not good enough for the extreme conditions, but it's not the norm.

Table 1. Perceptions of Voice Communications Between Non-Native English-Speaking Pilots and Native English-Speaking Controllers

\begin{tabular}{|l|c|l|}
\hline \multicolumn{1}{|c|}{ Voice Communications } & $\begin{array}{l}\text { Number } \\
\text { of Pilots }\end{array}$ & \multicolumn{1}{c|}{ Issues Discussed } \\
\hline Excellent & 1 & \\
\hline Very good in most respects & 22 & $\begin{array}{l}\text { Failure to Communicate Can Lead to Frustration } \\
\text { Proficiency Matters } \\
\text { Slower Speech Rates and Enunciate Clearly Are Key } \\
\text { Some Problems Are Universal } \\
\text { Taxi Clearances Are a Problem }\end{array}$ \\
\hline Could use some minor changes & 14 & $\begin{array}{l}\text { Failure to Communicate Can Lead to Frustration } \\
\text { Not Getting What You Expect to Hear } \\
\text { Some Controllers Facilitate } \\
\text { Some Problems Are Universal } \\
\text { Speak Slower and Use Standard Phraseology }\end{array}$ \\
\hline Not good enough for extreme & 10 & $\begin{array}{l}\text { Failure to Communicate Creates Safety Concerns } \\
\text { Language Barriers Affect All Pilots and Controllers } \\
\text { Non-Native English-Speaking Pilots and Controllers Work off Scripts }\end{array}$ \\
\hline Extremely poor & 0 & \\
\hline It varies & 1 & \\
\hline
\end{tabular}




\section{Slower Speech Rates and Enunciate Clearly Are Key}

It's been my experience that when talking to nonnative English-speaking pilots, most controllers have learned to avoid rapid speech rates and enunciate clearly. They had to face some of the same problems. You know, "Why should I have to repeat myself; I'Il just get it all done once-a little more slowly than I need to-but I'm going to give it all in the first transmission."

And foreign pilots seem to require less repeating and clarification. When they're not asking three times in a row, "What did you just tell me?" it tells me either they're being overly deferential or truly getting it. I think they're usually getting it. The pilots also seem to speak slowly and deliberately to be understood. So, I'm hearing a Korean pilot talking to an English controller, and they're trying to use their best English to communicate.

\section{Some Problems Are Universal}

The non-native English-speaking pilots experience the same problems we do of having controllers speak too quickly. The pilots ask for clarification just as we do in their countries. I am sometimes embarrassed by how controllers speak to non-native English-speaking pilots that come in. It has been my experience that in some U.S. airspace, controllers have less patience than others do. I find that the controllers in Los Angeles are generally more understanding, speak with a little more clarity, and with a little slower rate than controllers in New York.

\section{Taxi Clearances Are a Problem}

I haven't worked with any non-native Englishspeaking pilots but do hear problems now and again on the radio. The problems that I've heard have been with ground taxi clearances. The pilots do not understand where they're supposed to go.

\section{Could Use Some Minor Changes Explanation}

Of the 14 respondents who selected "Could use some minor changes," 12 provided a rationale for their response selection. The other two respondents had nothing to add. Like the pilots who selected "Very good in most respects," this group included "Failure to Communicate Can Lead to Frustration" as one of their six issues. The others, shown in Table 1, are discussed below.

\section{Failure to Communicate Can Lead to Frustration}

I'll never forget coming in from somewhere south, and Aeromexico was going in a direction they were not supposed to be going. I was actually amazed that we saw them fly by us, and the controller's trying to get him to turn around. So maybe their English isn't as good as it should be.

Controllers seem to lose patience when non-native English-speaking pilots have difficulty understanding. A few days ago, I was at Los Angeles International Airport (LAX) listening to the controller on the frequency. I heard frustration in his voice as he tried to explain (for the third time) something to a foreign crew. I really empathize because I wonder if a Japanese controller expresses the same frustration with me and would a Japanese pilot hear it in his voice when I'm having to ask "say again" for the third time.

\section{Not Getting What You Expect to Hear}

We hear non-native English-speaking pilots in Los Angeles and Chicago. Some are very fine; and others aren't. It's almost as if ATC cannot communicate with them. The whole system drags down just for a few moments.

I think it's just like when we're over there, not expecting what I'm hearing. Now, they're going to get something that they're not expecting; and it'll require a lot more effort to get that point across between the pilot and controller-I see that as being an issue.

\section{Some Controllers Facilitate}

In Atlanta, I've heard controllers take their time with non-native English-speaking pilots and help them along. The controllers pretty much have to give some of these pilots baby steps as they go along.

\section{Some Problems Are Universal}

It seems to me that the effort of non-native Englishspeaking pilots is similar to our effort to understand in their countries. They're trying to understand our controllers who speak rapidly in our native dialect and slang. As pilots, we try to keep the jargon down to a minimum-keep it short, concise, right to the point. It doesn't matter if we're native English-speaking or non-native English-speaking pilots-we assume we're going to hear a certain thing back when we check in and so on. When we don't, it's nonstandard.

Controllers may be a little more relaxed when they speak with us, and they're native English speakers. But, if they have a non-native English-speaking pilot, they may make the assumption that, "I have to be careful and choose my words carefully with this particular pilot." I've found that non-native English-speaking pilots have a harder time understanding clearances, frequency changes, taxi routes etc.

\section{Speak Slower and Use Standard Phraseology}

In terminal airspace, when it is very busy, controllers and native English-speaking pilots frequently speak quickly and sometimes abbreviate their transmissions. If pilots are from there, they pretty much know where ATC wants them to go, et cetera.

When the controller gets a foreign air carrier that doesn't fly here often and the pilots don't understand English as well, it bogs down the system. It would probably be best if controllers would speak slower and with air traffic control phraseology and terminology when speaking to international aircraft. That would cut down on repeat clearances. 


\section{Not Good Enough for Extreme Conditions Explanation}

All 10 respondents participated in the discussions, and we identified three issues. All of their issues concentrated on safety.

\section{Failure to Communicate Creates Safety Concerns}

I find pilots from some countries have a very distinct language barrier. They seem to do very well being cleared through a point if the controller says something such as "turn two seven zero" and assigns a particular altitude. But, if ATC says, "Turn two seven zero, I'm going to run you out about 20 miles to get you around these guys," they don't understand what the controller wants them to do and will request a "say again." So, it seems to me as though controllers expect more of a level of competency than what I hear, especially under some duress or high-pressure situations.

It's been my experience that non-native Englishspeaking pilots have problems in Chicago, Los Angeles, Miami, New York, and some other U.S. airports. I have seen some dangerous things purely because of a lack of communication. We've had near-misses, taxiing situations, airplanes cleared for takeoff [executed by] another airplane.

\section{Language Barriers Affect All Pilots and Controllers}

So, now [our discussion] goes from what we were talking about earlier-English-speaking pilots trying to talk to controllers who don't speak English as their first language to non-native English-speaking pilots trying to talk to English-speaking controllers. And I'm sure they're doing the same thing we do [when we don't understand]-they are asking each other, "What did he say? I don't know what he said."

This example mirrors a problem we had in Atlanta. A non-native English-speaking pilot was given taxi instructions and ended up somewhere where he wasn't supposed to be. There was a miscommunication between him and the ground controller. We became distracted from our own operation because we were trying to figure out where he was [in proximity to us]. It was not a good thing to hear on the radio.

\section{Non-Native English-Speaking Pilots and Controllers Work off Scripts}

A lot of non-native English-speaking pilots and controllers only learn so many words and phrases and basically work off a script. So, how do I know this is a problem for non-native English-speaking pilots? I hear long periods of silence after controllers ask them a nonstandard idiomatic question in English. When [non-native English-speaking pilots] get into a nonstandard situation, they cannot adjust.

Interviewer: Can you characterize what you mean by nonstandard?

Deviations around thunderstorm, traffic conflict, things like that.

54a. When you hear international non-native Englishspeaking pilots, what tells you whether they are high or low in English language proficiency?

One subject matter expert who had previously coded similar data (Question 39a; Prinzo et al., 2010c) and the first author (Coder 1) independently coded the pilots' responses to this question using Doc 9835 (ICAO, 2004). Key words served to filter pilots' comments and remarks. For example, "pronounced words" was coded Pronunciation while "conjugating verbs" was coded Structure. This process was performed on 79 items. Neither coder could determine an appropriate category for "tone of voice," "intuitive having problems," and "by their standard communication procedures," so these items were removed.

Table 2 shows the percentages of agreement between the coders. Krippendorf's alpha (Hayes \& Krippendorff, 2007) was computed as a measure of agreement and it was $=.83$, indicating a high degree of reliability. The results show the coders were in total agreement on Interaction, Structure, and Vocabulary but less so on Comprehension, Fluency, and Pronunciation.

Table 3 shows how often pilots used a particular category to evaluate the language proficiency of non-native English-speaking pilots. A chi-square test of goodness-offit revealed Comprehension, Fluency, and Pronunciation descriptors were used more often to determine the level of English language proficiency, $\chi^{2}(5)=25.37, p<.05$. This result indicates that the U.S. pilots who participated in

Table 2. Inter-Coder Agreement Classifying Pilot Judgments of Controller Language Proficiency

\begin{tabular}{|l|c|}
\hline \multicolumn{1}{|c|}{ ICAO Categories of Language Proficiency } & Agreement \\
\hline Comprehension & $84 \%$ \\
\hline Fluency & $89 \%$ \\
\hline Interaction & $100 \%$ \\
\hline Pronunciation & $81 \%$ \\
\hline Structure & $100 \%$ \\
\hline Vocabulary & $100 \%$ \\
\hline
\end{tabular}


Table 3. How Pilots Determine Non-Native English-Speaking Pilots' Language Proficiency

\begin{tabular}{|c|c|c|}
\hline $\begin{array}{l}\text { ICAO Categories of } \\
\text { Language } \\
\text { Proficiency }\end{array}$ & $\begin{array}{l}\text { Percentage } \\
\text { of Instances }\end{array}$ & $\begin{array}{c}\text { ICAO Descriptors } \\
\text { (Level 6, Expert and Level } 3 \text { Pre-Operational) }\end{array}$ \\
\hline Comprehension & $28 \%$ & $\begin{array}{l}\text { L6 Comprehension is consistently accurate in nearly all contexts and } \\
\text { includes comprehension of linguistic and cultural subtleties. } \\
\text { L3 Comprehension is often accurate on common, concrete, and work- } \\
\text { related topics when the accent or variety used is sufficiently intelligible } \\
\text { for an international community of users. May fail to understand a } \\
\text { linguistic or situational complication or an unexpected turn of events. }\end{array}$ \\
\hline Fluency & $28 \%$ & $\begin{array}{l}\text { L6 Able to speak at length with a natural, effortless flow. Varies speech } \\
\text { flow for stylistic effect, e.g. to emphasize a point. Uses appropriate } \\
\text { discourse markers and connectors spontaneously. } \\
\text { L3 Produces stretches of language, but phrasing and pausing are often } \\
\text { inappropriate. Hesitations or slowness in language processing may } \\
\text { prevent effective communication. Fillers are sometimes distracting. }\end{array}$ \\
\hline Interaction & $12 \%$ & $\begin{array}{l}\text { L6 Interacts with ease in nearly all situations. Is sensitive to verbal and } \\
\text { non-verbal cues and responds to them appropriately. } \\
\text { L3 Responses are sometimes immediate, appropriate, and informative. } \\
\text { Can initiate and maintain exchanges with reasonable ease on familiar } \\
\text { topics and in predictable situations. Generally inadequate when dealing } \\
\text { with an unexpected turn of events. }\end{array}$ \\
\hline Pronunciation & $22 \%$ & $\begin{array}{l}\text { L6 Pronunciation, stress, rhythm, and intonation, though possibly } \\
\text { influenced by the first language or regional variation, almost never } \\
\text { interfere with ease of understanding. } \\
\text { L3 Pronunciation, stress, rhythm, and intonation are influenced by the } \\
\text { first language or regional variation and frequently interfere with ease of } \\
\text { understanding. }\end{array}$ \\
\hline Structure & $5 \%$ & $\begin{array}{l}\text { L6 Both basic and complex grammatical structures and sentence } \\
\text { patterns are consistently well controlled. } \\
\text { L3 Basic grammatical structures and sentence patterns associated with } \\
\text { predictable situations are not always well controlled. Errors frequently } \\
\text { interfere with meaning. }\end{array}$ \\
\hline Vocabulary & $5 \%$ & $\begin{array}{l}\text { L6 Vocabulary range and accuracy are sufficient to communicate } \\
\text { effectively on a wide variety of familiar and unfamiliar topics. Vocabulary } \\
\text { is idiomatic, nuanced, and sensitive to register. } \\
\text { L3 Vocabulary range and accuracy are often sufficient to communicate } \\
\text { on common, concrete, or work-related topics, but range is limited and } \\
\text { the word choice often inappropriate. Is often unable to paraphrase } \\
\text { successfully when lacking vocabulary. }\end{array}$ \\
\hline
\end{tabular}


this study used Comprehension, Fluency, and Pronunciation to a greater degree to evaluate language proficiency than Interaction, Structure, and Vocabulary. A discussion of their various techniques follows.

\section{Comprehension}

It's relatively obvious to me that non-native Englishspeaking pilots' proficiency is low if they're having trouble understanding the clearances and are having trouble communicating. My first clue of [their proficiency] level is from the number of repeats and then how long that dialogue takes.

\section{Fluency}

I can tell by the speed of the pilots' [individual] words, their rate of speech, and scope of vocabulary. Do pilots speak just a set phrase or do they speak with fluency? I might hear a pilot stutter or have pure urgency in his voice when asking for a repeat.

\section{Interaction}

Are controllers getting their point across the first time, or are they in a debate with the pilot? Do the controllers have to slow their speech and, instead of giving a whole rapid-fire clearance, give it in pieces? Instead of saying, "Turn two seven zero descend four thousand feet, slow to a hundred and eighty knots, intercept the ILS ${ }^{1}$ two seven left," first they'll give a heading and an altitude, then a speed, and finally the approach.

I can tell by how pilots react whether they got it or not. Are they slow to respond or do they come right back? The worst thing I want to hear after ATC's given a clearance is silence. If I hear nothing, a long hesitation, a really slow readback, or an incorrect readback, then I know there's trouble.

\section{Pronunciation}

Also, pronunciation is a clue as are enunciation, the flow of their communication, and the deliberateness of communications. The accent I hear may tell me something-but it varies greatly from pilot to pilot.

\section{Structure}

The conjugation of verbs and the vocabulary have a tendency to stick with you. One-syllable words, easy-to-understand words, or a repeat request. He or she has the ability to make a sentence.

\section{Vocabulary}

Are they able to go a little bit beyond ICAO standards if they're dealing with something outside the normal? I'm listening to get a sense of whether they are good or are just using ICAO communication in a standard manner.

\footnotetext{
${ }^{1}$ Instrument Landing System.
}

54b. With regard to communication tasks, what do you do when a non-native English-speaking pilot and you are on the same flight path and you suspect that pilot is low in English language proficiency skills?

The pilots' responses from the written and interview portions of the questionnaire were grouped into two major categories: those stemming from Communication-Based Actions and Non-Communication-Based-Activities. They appear in Table 4, followed by a summary of some of the key points. We assumed they had access to complete partyline communications. However, during our discussions, it became apparent that was not always the case. Thus, the items in Communication-Based Actions were grouped according to the absence and presence of party-line communications. An examination of the items within each category revealed $45 \%$ of the listed Communication-Based Actions centered on Message Reception on the Flight Deck, $30 \%$ on Message Production From the Flight Deck, and $25 \%$ on Resolve Ambiguities/Doubts.

In a similar fashion, $56 \%$ of the Non-CommunicationBased-Activities involved Navigate activities and $44 \%$ on Utilize More Cognitive Resources activities. One respondent made no comments, while two others said they would not do anything differently or communicate directly with the pilots, and one said he had not encountered this.

\section{Communication-Based Actions Message Production From the Flight Deck Phraseology}

I try to use ICAO terms that they understand and stay away from Common English terms that might confuse low English-proficiency pilots. I had the same experiences in one of their countries. I'm thinking how it is for me when I don't understand, and I think they're feeling a little helpless in this situation too. If I'm given a similar clearance, I say it back slowly and clearly, so maybe they might hear the same thing again.

\section{Speech Production}

What I'll do is speak slowly, distinctly, and clearly. If I have something to say right away, I try to let them finish their conversation and then get on with what I need to talk about. I usually delay what I need to do to make sure they understand what's going on in front or behind me. I have to be patient and may not get timely clearances if the crew ahead of us has problems.

\section{Message Reception On the Flight Deck Absence of Party-Line Communications}

At some of the busier airports, there are separate tower frequencies for each runway so we don't hear what's going on at the other runways. In my opinion, the threat from a non-native English-speaking pilot with low proficiency skills occurs if we're on parallel approaches-especially if we're joining adjacent 
Table 4. List and Frequency of Pilot's Actions to Improve Understanding a Non-Native English-Speaking Pilot Whose English-Language Proficiency is Low

\begin{tabular}{|c|c|}
\hline Theme & Pilot Actions \\
\hline \multicolumn{2}{|l|}{ Communication-Based Actions (40) } \\
\hline \multicolumn{2}{|l|}{ Message Production From the Flight Deck (12) } \\
\hline Phraseology (4) & $\begin{array}{l}\text { "Yes" and "No" questions; Stay away from Common English; } \\
\text { Use only ICAO phrases, vocabulary, terms }\end{array}$ \\
\hline Speech Production (8) & $\begin{array}{l}\text { Don't interrupt and remain patient; Speak clearly and } \\
\text { concisely; Speak slowly }\end{array}$ \\
\hline \multicolumn{2}{|l|}{ Message Reception On the Flight Deck (18) } \\
\hline Crew Resource Management (4) & $\begin{array}{l}\text { Confer with crewmembers about their understanding of the } \\
\text { message; Make sure every crewmember listens attentively }\end{array}$ \\
\hline Sensory and Attentional Resources (14) & $\begin{array}{l}\text { Listen more attentively to his clearances and readbacks; } \\
\text { Listen more intently; Listen to the controller }\end{array}$ \\
\hline \multicolumn{2}{|l|}{ Resolve Ambiguities/Doubts (10) } \\
\hline Be Part of the Readback-Hearback-Loop (4) & $\begin{array}{l}\text { Ask ATC for clarification or verification of other aircraft's } \\
\text { intentions; Offer to translate }\end{array}$ \\
\hline Don't Become Part of the Problem (6) & $\begin{array}{l}\text { Ask to breakaway and come back later; I tell him what I am } \\
\text { doing }\end{array}$ \\
\hline \multicolumn{2}{|l|}{ Non-Communication-Based-Activities (39) } \\
\hline Navigate (22) & $\begin{array}{l}\text { Use all available SA cues (monitor TCAS } \text {, have a map out, } \\
\text { back radio, offset routes); Plan ahead (expect the } \\
\text { unexpected, anticipate actions, have a map out) }\end{array}$ \\
\hline Utilize More Cognitive Resources (17) & $\begin{array}{l}\text { Increase attention, awareness, caution, vigilance; Pay closer } \\
\text { attention to his position, aircraft flight path, and intentions; Try } \\
\text { to understand their situation }\end{array}$ \\
\hline
\end{tabular}

a Traffic Alert and Collision Avoidance System.

localizers. If he doesn't have the right ILS frequency tuned in, he's going to stray onto our flight path on down the localizer.

An even higher threat is on the ground, where he's straying onto our runway as we're taking off or landing. I don't know if he's being cleared to cross the runway in front of me as I'm landing, because he's on a different frequency. I don't know if he's been cleared to take off, or he thinks he's been cleared to take off because I'm on a different frequency.

\section{Presence of Party-Line Communications}

I try to get any available crewmember to actively listen to what's going on the radio. Maybe they can help me pick up what's going on. Here [in the U.S.] we have an advantage because we all speak a language that we understand and are listening for the non-native English-speaking pilot's responses.

We can pretty much determine where the non-native English-speaking pilot is from what the controller is telling him to do. We pay close attention to his position and understanding of his clearances. We can determine how that is going to impact our flight or if he is going to have any affect on us.

Interviewer: How do you pay close attention to his position; what do you use to do that?

Well generally, if we're coming in on an arrival and someone checks in on the radio, he's going to be behind us. That's our first clue. Then he'll be given a clearance that's probably similar to the one we received. As the pilot reads it back, the controller [might be thinking about] giving a clearance to another airplane and doesn't hear that the readback was either incorrect or incomplete. And that causes a concern for me. So, rather than do things to help a non-native English-speaking pilot, I go inward-I'm going to be more vigilant; I' $m$ going to keep track of him; and I'm going q.t. ${ }^{2}$ and listen to his calls and his readbacks with the hearback.

\section{Resolve Ambiguities/Doubts \\ Be Part of the Readback-Hearback-Loop}

There are times when I want to get on the radio and say, "Hey, he said this altitude or this heading," or, "I don't think he understood that." In some situations, the controller might not hear [the pilot's readback]; and I know the pilot's going to the wrong altitude and maybe I can help-or certainly keep my aircraft safe.

If a controller's telling a non-native English-speaking pilot three times to do something and he's not getting it, a little intervention helps. It's probably not the best, but if needed, I would interpret for ATC or the other aircraft. The most I've ever done when things really went south was say to the controller, "Hey

\footnotetext{
On the quiet.
} 
slow down; I can't understand you either."

If a conflict was to exist and timing was critical, I would not hesitate to speak up. Sometimes, another pilot telling ATC something a little bit differently, slowly, and with terms that are easily understood helps the non-native English-speaking pilot as he listens to that pilot.

\section{Don't Become Part of the Problem}

I don't want to be near a potential situation where a non-native English-speaking pilot doesn't understand where he's to operate his airplane. If I know he is not communicating clearly with the controller, it's only human nature to want to find out where that pilot is and then get as far away as possible from him because I don't want to be part of the problem.

If there's some sort of conflict, I broadcast what I'm doing and what my intentions are, but I don't tell them what to do. I tell them exactly what I'm doing and then I monitor them. So, I communicate in very plain, short, and concise language exactly what I'm doing.

\section{Non-Communication-Based-Activities Navigate \\ TCAS Is Golden}

To know what's going on, I use all the available situational awareness clues that I have-the TCAS, perhaps the back radio air-to-air, a map, the terminal area chart or any chart, or anything that I can pick up some routing off of. I'Il monitor TCAS, but he might be outside of its range. If he is an issue on TCAS, we're probably going to see it right away anyway. WithoutTCAS, it would be harder to try and find him. Interviewer: What do you mean by the back radio?

We can set the number two VHF radio to an air-toair frequency, a company frequency, or what have you. Sometimes, especially enroute, if we're having these kinds of problems I can come up on the back radio - the off ATC frequency - and say, "Hey, did ATC mean this, or did he mean that, or can anybody hear him and relay for me?"

If I can hear what the controller says to the lowproficiency pilot, at least I have a little better situational awareness. If I wanted to talk to him aside from ATC, maybe I could do that too.

\section{Offset Routes}

Offsetting a specific route or an airway is a very significant thing to do and a great idea. One of the consequences of improved navigation systems using

\footnotetext{
${ }^{3}$ This is in reference to lateral offsets. The provision in ICAO Annex 2 Rules of the Air requires that aircraft operating controlled flights shall, when on an established ATS route, operate along the defined center line of that route has provision for exceptional arrangements if these are authorized by the appropriate ATS authority, or directed by ATC. Furthermore, Annex 2, 3.6.2.1.1 requires authorization for the application of strategic lateral offsets from the appropriate ATS authority responsible for the airspace concerned. The arrangements for such an exception are detailed in ICAO Doc 4444 PANS-ATM.
}

GPS, ${ }^{4}$ and the accuracy of that system, is that we inherently get a higher probability of [airplanes] along an assigned route of flight being in closer proximity of one another. If we happen to be on coinciding flight paths, we have the same problem and may have to use our guidance system to offset from that airway. If everybody is using that type of system, it actually increases safety significantly.

\section{Plan Ahead, Expect the Unexpected, Anticipate Actions}

I fly my airplane to the best that I can, listen intently, use TCAS, and everything else that I can to try to keep myself clear of problem situations. I plan for conflict resolution, just in case he overshoots the localizer. I want ATC to give me a little extra space-I have to anticipate he could do what I don't want him to do.

My experience is that it degrades situational awareness to the point where if an airplane is down at the far end of the runway waiting to cross the runway-and it's [name foreign carrier] — and we're in LA, we have be ready for the pilot to cross the runway in front of us. We have to be on the defensive and anticipate a blunder on his part.

\section{Utilize More Cognitive Resources}

I've learned to increase my vigilance by making sure that I'm listening to what the non-native Englishspeaking pilot with low English proficiency is trying to say back to the controller. I don't know if he really understands the clearance. I'm exercising extreme awareness trying to understand where he is, where he's going, and what it is that I think he understands with regards to his clearance.

To do this, I turn up my situational awareness because I know he's out there kind of flailing around, and he's not really able to communicate very well with the controller. I know where we're going but still question where he's going. So we are very aware, and fly with a TCAS turned on. It demands a great deal of attention, diligence, and we scan outside the cockpit even more often.

\section{U.S. Controllers' Handling of Low English-Language Proficiency Pilots Varies}

It's been my experience that sometimes U.S. controllers can be a little lax with foreign pilots. Still, I find that controllers are good at resolving ambiguity and making sure that pilots are going the right way. The controllers get after them and ask them over and over again until they understand.

But, sometimes controllers assume a particular pilot is familiar with their airport. One of the results of that is that we almost had an incident on a runway. There was a foreign 747 on the runway that was probably lost, and we went right over the top of them.

Interviewer: What's your experience with how U.S. controllers handle international flight crews?

I think it depends on the experience of the controller

\footnotetext{
${ }^{4}$ Global Positioning System.
} 
most of the time. The controllers deal with international flight crews every single day, and it's been my experience that most controllers treat them really well. I think the controllers get a quick read on how proficient the pilot is with English. Once that happens, they know how much they have to clean up their phraseology-say it very slow and make it concise - or, use a little bit of jargon. Also, it seems to me that some U.S. controllers get a little more impatient with foreign-speaking pilots if they don't understand a clearance given once or twice.

\section{How mightnon-native Englishspeakingpilots' commu- nications with international native English-speaking controllers differ from that of pilots and controllers who speak English?}

There were 42 pilots who provided written responses, and six pilots left the question blank. As seen in Table 5, approximately $47 \%$ of their written responses involved Radio Communication Protocol. Another 27\% were related to Pilot-Controller Interactions and $16 \%$ to Performance, and $10 \%$ to Non-Standard Terms and Procedures. The numbers in parentheses reflect the number of times an item was grouped into a category.

The majority of the dialogue resulted from questions asked by the interviewers during the focus group discussions. The pilots' compiled comments from the written and interview portions of the questionnaire and interviewers' questions are included below.

\section{Performance}

\section{Non-Native English-Speaking Pilots May Not Be Fluent and Talk Less}

Interviewer: You mean that you talk on the radio less? When I hear non-native English-speaking pilots and native English-speaking controllers talking, they use standard communication. The pilots are slower and less likely to be able to handle a difficult clearance or a situation requiring communication beyond ICAO standard. If pilots are not fluent in English, they can't say they have a problem, need to hold at a particular location, or need to descend right now-there is no jargon, but concise communications.

\section{Missed Calls and Misunderstanding Are the Differences}

My thought on that, from experience, was that missed calls in a heavy radio traffic environment tend to be more frequent when this combination arises. Sometimes in Chicago, there's a lot of repeating of clearances with [name airline] pilots because they have trouble understanding a clearance.

Table 5. Perceived Differences in Communication Between Native and Non-Native English-Speaking Pilots and Controllers

\begin{tabular}{|c|c|}
\hline Differences In Communications & Items \\
\hline Performance (8) & $\begin{array}{l}\text { Controllers devote more time to them; It takes more time; } \\
\text { Controller efficiency goes down; Higher work load for } \\
\text { controllers; Less likely to handle difficult clearance or situation } \\
\text { requiring communication; Missed calls in heavy radio traffic } \\
\text { environments; U.S. controllers expect more rapid compliance } \\
\text { with instruction until the pilot has difficulty with communication; } \\
\text { Lack of familiarity with local procedures. }\end{array}$ \\
\hline Pilot-Controller Interactions (14) & $\begin{array}{l}\text { Slower response times; Longer response times; Increased } \\
\text { communication; Less extraneous conversations; Non-native } \\
\text { English-speaking pilots seem to ask more questions; More } \\
\text { repeating of instructions, clearances, commands, phrases } \\
\text { between them; More repeats and clarifications, more readbacks } \\
\text { and clarifications; Request an explanation of any jargon used; } \\
\text { Minimal communication. }\end{array}$ \\
\hline Non-Standardized Terms and Procedures (5) & Failure to understand; Difficulty understanding clearances. \\
\hline \multicolumn{2}{|l|}{ Radio Communication Protocol } \\
\hline $\begin{array}{l}\text { Message Contents by Speaker-Listener } \\
\text { Composition (12) }\end{array}$ & $\begin{array}{l}\text { More formal; Communication must be concise and to the point; } \\
\text { Limited to ATC English; Less nonstandard terminology; More } \\
\text { emphasis on ICAO standard and less extraneous conversation; } \\
\text { Native English-speakers seem to use more plain English; Non- } \\
\text { native English-speaking pilots use ICAO terms/terminology; May } \\
\text { not understand slang or jargon used by U.S. controllers. }\end{array}$ \\
\hline Message Structure (4) & $\begin{array}{l}\text { Messages tend to be scripted; Short sentences; Short phrases } \\
\text { with minimal extra verbiage. }\end{array}$ \\
\hline Speech Production (8) & $\begin{array}{l}\text { Native English-speakers take less time to communicate; Short } \\
\text { responses; Others will likely be slower. }\end{array}$ \\
\hline
\end{tabular}




\section{Pilot-Controller Interactions}

Alters the Ebb and Flow of Operational Communications

It's been my experience that if a non-native Englishspeaking pilot's talking in English to a native Englishspeaking controller, the controller will have to build time because communication will be more time consuming, slower, and deliberate.

When Atlanta gets up and popping, to the point of where they're rolling the numbers upwards of 100 to 110 flights per hour coming in, it can be as if you're at an auction-fast and there's a flow that develops. There are times when the controllers can run traffic like an absolutely wonderful machine. And I think, "These guys are good." But, it's not only them-it's the whole process that's good.

If a language problem is thrown in, it can mess up the cadence to the point where controllers spend more time with a non-native English-speaking pilot. Instead of giving multiple clearances in a message, they break it up into pieces. If they don't, they know the pilot will ask for a repeat, and that's going to slow down the operation even more.

\section{Non-Native English-Speaking Pilots Ask More Questions}

While there are fewer introductions, sign-offs, and extraneous conversations, the controllers make more repeated commands and clarifications because pilots ask more questions. English-speaking controllers may use jargon that is not understood by international pilots. When that happens, the foreign pilots usually request an explanation of any jargon used.

\section{Non-Standardized Terms and Procedures}

The non-native English-speaking pilots in Englishspeaking countries most likely experience the same frustration levels as native English-speaking pilots do in other countries. [The same goes with the controllers.] We're all dealing with the same frustrations due to the non-standardization of terminologies and procedures.

The conversations that I hear in non-native Englishspeaking countries are basically the same as those by U.S. controllers with non-native English-speaking pilots. If everything's working nicely, there is no difference between what we're doing and what they're doing, and it seems to work fairly well.

But, non-native English-speaking pilots use ICAO terms and terminologies that may not be readily comprehended by U.S. controllers. A few days ago as I was leaving [airport], the controller said, "Position and hold runway twenty-two right," and the pilot read back, "I will line up and wait on twenty two right." He used the ICAO terminology and the U.S. controller said, "Read back position and hold." It's the same thing that I struggle with in their environment. Again, it's probably a lack of understanding, and it probably results in increased communications between the pilots and controllers to resolve clearances.

\section{Radio Communication Protocol}

Message Contents by Speaker-Listener Combination

Native English-Speaking Controllers and Non-Native English-Speaking Pilots

From what I've heard on frequency, native Englishspeaking controllers are real concise and enunciate what they have to say because I'm assuming they're aware of the language problem. So, they're not going to chit-chat in fear of misunderstandings; they're going to be succinct, and this shortens communication times.

If there is an issue and things change, then it really breaks down. The pilots don't know what the U.S. controller is telling them at that point, and that's where the issues come up. When there's a breakdown in communications, controllers stick to ATC verbiage and hopefully get the point across.

Interviewer: As you are listening to the radio, how would the native English-speaking controller be talking to a non-native English-speaking pilot?

Our controllers are more direct and concise with a foreign carrier than they are with us. That's pretty much what I've experienced flying into Atlanta and NewYork; generally, that is what I'Il hear. The controllers won't give them as complicated an instruction. There won't be a turn right heading two four zero join two four right localizer contact tower one one nine decimal three. They won't say all that. They'll tell them, "Turn right heading two four zero to join the localizer." They'll break up the communications. I definitely see that.

Interviewer: Because you're hearing all this on the headset and sizing up what's going on with that pilot and controller, how is it going to affect you?

It will, because the pilot may not understand what ATC said and may translate it wrong. If he rolls out, that'll put me in a go-around situation, and I might be low on fuel.

\section{Native English-Speaking Controllers and Native English-Speaking Pilots}

English-to-English speaking pilots and controllers seem to use a little more plain English, which I believe improves communication. I'm thinking in terms of ride reports and weather reports, and nonclearance chatter that would fit into the standard phraseology. This rarely occurs with the non-native English-speaking pilots.

In the U.K., I feel controllers don't treat us any differently. They'll give us a long series of instructions and expect us to comply with them. But, I don't hear non-native English-speaking pilots that often over there. I'm listening more intently to what the controllers are telling me, and not so much to what they are telling everybody else. And that's an interesting aside, because it's much easier operating in the U.S. to hear what's going on all around us than it is even in the U.K. When we get there, we're tired. 


\section{Message Structure}

Interviewer: Have you noticed whether U.S. controllers send a non-native English-speaking pilot less information in a transmission than they would to a native Englishspeaking pilot?

The initial contact, for the most part, is the same, but if the controllers don't get the response they want, then they'll break it down. Communication tends to be very scripted and, depending on the pilot's fluency, can become more stilted.

Interviewer: You mentioned earlier that some controllers will send out multiple clearance items plus a change in radio frequency and altimeter. Do you think that also happens for their communication with the non-native English-speaking pilot?

I have not heard controllers load them up to the extent that they load us up. It's not unusual for us to check in with New York Approach and get, "After Metro fly heading zero two zero descend to six thousand feet squawk zero one five three altimeter two nine five eight." And, "Oh, by the way, slow to two ten." Non-native English-speaking pilots get this information spaced out over three or four transmissions.

Interviewer: How many instructions would be in an optimal transmission?

Speaking for the four of us, I think a heading and altitude [is enough]. Two number-based clearances is as much as I want to do for one communication. I don't want the altimeter setting, I don't want a new squawk, and I don't want a frequency.

\section{Lack of Confidence and Familiarity- Communication Scripted}

In New York and Chicago, we're expected to do things a certain way. The non-native English-speaking pilots lack a familiarity with local procedures and do not comply. I see that quite often. For example, the controllers expect pilots to fly a hundred and seventy [knots] to the marker, but they slow down early-to a hundred and forty to the marker.

\section{Speech Production}

I don't think controllers slow down the speed at which they communicate with the foreign carriers, which exacerbates their problem. Depending on the foreign carrier, the pilots may have to ask the controller repeatedly what was said. And then it just gets louder but not any slower.

Some [non-native English-speaking pilots] who hesitate between words, is a tip-off. I find that happens frequently. But if that's what they have to do to safely communicate their desires, I can live with that.

\section{Communication Is Slower and Takes More Time}

It takes less time to communicate between an English-speaking pilot and controller. U.S. controllers will speak quite rapidly until they perceive a problem, and then they'll start to speak more slowly and more directly.

Generally, non-native English-speaking pilots who come into the U.S. are pretty good with English. And it's not a real struggle to convey to them what the controllers want them to do. The non-native Englishspeaking pilot and English-speaking controller will take a little longer for the same reasons that it takes us longer when we're in Mexico or elsewhere. Communications are a little bit slower, a little bit more deliberate because it takes a little more time to translate. Like us, they're choosing their words more carefully, saying them slower; hopefully, it's more concise.

\section{Transmission Structure Changes to Ensure Compliance}

Interviewer: You mentioned earlier that if the controller suspects a pilot's English isn't all that great-it's adequate - that you think they send less information. Do they do that as a habit or only if they detect a problem?

When controllers detect a problem, they wouldn't really key in on language as much as compliance and understanding. It's been my experience that controllers seem to assume a high level of competency until there's a proven problem or issue; then they start breaking the clearance up into smaller pieces. They feed you these pieces until they solve the problem and move on from there.

Interviewer: Do you ever hear them doing that with a native English-speaking pilot?

Yes, but only in a student pilot role. And it comes down to, "Who are you? Where are you? And what do you want?" That's a perfect example too, because that's the difference between knowing what you're expecting to hear and hearing it for the first time. It's like going into a foreign country for the first time. Controllers are saying things to pilots that they've never heard before. The same with a student pilot-he gets in there, the first time he taxis out, they're telling him to do things that he read about in a book. Everything's a surprise, every single word practically; it's a lot like us flying in other continents.

\section{Controllers Accommodate Differences in Pilot English Proficiency}

Interviewer: Are some pilots from different countries more proficient in English?

Absolutely, when some of the new countries that just joined the $\mathrm{EU}^{5}$ fly into New York, the pilots have trouble speaking English because they have not had to use it in their aviation system in the old Soviet Bloc. They don't use English, so it's novel. The controllers tend to devote more time to the nonnative English-speaking pilots just to make sure they understand what's going on. Sometimes the readback can get a little slower; and in New York that's a big thing because everybody makes comments on the frequencies.

\footnotetext{
Possibly referring to the European Union.
} 


\begin{tabular}{|c|l|c|c|}
\hline \multicolumn{2}{|c|}{} & \multicolumn{2}{c|}{ Controller } \\
\cline { 3 - 4 } \multicolumn{2}{|c|}{} & English (E) & Other than English (O) \\
\hline \multirow{3}{*}{ Pilot } & English (E) & Q56 EE & Q41 EO \\
\cline { 2 - 4 } & Other than English (O) & Q56 OE & Q41 OO \\
\hline
\end{tabular}

Figure 1. Comparison Between Language Relationships in Question 41 and Question 56

If the initial response from the airplane is a little slower, then the controller tends to talk a little slower. The controllers speak fast to us; and by slowing down their English for some non-native English-speaking pilots, they actually speed up the operation; they don't have to repeat themselves three or four times.

\section{U.S. Controllers Have Their own Phraseology}

I think it's harder for non-native English-speaking pilots to come to the U.S. than it would be for us to go over there because the ICAO phraseology is normally used overseas. It's a lot less standard in the U.S.

Interviewer: How often do you hear the U.S. controllers using ICAO phraseology with non-native Englishspeaking pilots?

The U.S. has its own phraseology so maybe $20 \%$. It is probably more difficult for non-native Englishspeaking pilots. Controllers expect the same behavior in terms of complying with clearances; but when they're talking to pilots, they don't use the same phraseology. Why is that different? Everybody knows what the ICAO standard is. Why aren't we doing that? But again, if you're talking about being in the United States, it's the same from Alaska to Florida versus going to Europe. In Europe, we have to deal with England's procedures, France's procedures, Amsterdam's procedures; so, that also becomes a problem.

\section{Failure of Air China's Pilot to Understand Plain English}

This is the Air China/LAX example of a failure to understand on the part of the pilot where he had a locked brake. All I know is that Ground tried to talk to him, but he switched to Tower and tried to take off. Tower said, "You're not cleared for takeoff, exit the runway right here," and it took several times. We spoke English perfectly and the controller spoke English perfectly, but the non-native English-speaking pilot couldn't understand us. We could not communicate with him, period. I'm not sure if ATC got him off the runway; we took off and we never heard what happened.

56. During a typical international flight, about how much time do non-native English speaking pilots and international native English-speaking controllers spend talking as compared with pilots and controllers who speak English?
This question parallels question 41 found in Report 4 (Prinzo et al., 2010c). The relationship between the two questions is illustrated in Figure 1. Question 41 asked the pilots to compare the amount of time native Englishspeaking pilots (e.g., Australian, English, Irish, New Zealander, U.S.) and international non-native Englishspeaking controllers (e.g., Arabic, French, Mandarin Chinese, Russian, Spanish) spend talking as compared with pilots and controllers who speak the same nonnative English language (e.g., both speak Arabic, French, Mandarin Chinese, Russian, Spanish to each other). Question 56 asked the pilots to compare the amount of time non-native English-speaking pilots and native English-speaking controllers spend talking to each other compared with pilots and controllers who both speak English as their native language.

The respondents' compiled comments from the written and interview portions of the questionnaire are summarized in Table 6 . It shows that only $6 \%$ of the pilots reported non-native English-speaking pilots spent "considerably more" time communicating with native English-speaking controllers, compared with pilots and controllers who spoke English. Another 48\% reported the time spent as "more," $21 \%$ reported it as "less," and 8\% as "considerably less." The remaining $17 \%$ reported the time to be "about the same" regardless of language pairing.

\section{Considerably More Time Spent Communicating Explanation}

Of the three respondents who said non-native English-speaking pilots spend considerably more time communicating with English-speaking controllers, one explained his selection.

\section{Language Constraints Cause Repeats, Slower Speech, Fewer Requests, and Controller to Reduce Clearance Items}

It's been my experience that their communication seems to be limited due to language constraints, so there are fewer questions, requests for direct routing, altitude changes, ride reports, baseball or football scores, and things of that nature that we typically hear between English-speaking pilots and controllers. They need to speak more slowly, and things need to be repeated. Controllers give instructions piecemeal, rather than in one long, clean transmission because they understand they can't give four or five or even three instructions in one transmission because it will all come apart. 
Table 6. Pilots' Perceptions of Time on Frequency Communicating Between Non-Native and Native English-Speaking Pilots and Controllers

\begin{tabular}{|l|c|c|l|}
\hline $\begin{array}{c}\text { Time Spent } \\
\text { Communicating }\end{array}$ & $\begin{array}{c}\text { Number } \\
\text { of Pilots }\end{array}$ & $\%$ & \multicolumn{1}{c|}{ Issues } \\
\hline Considerably more & 3 & 6 & $\begin{array}{l}\text { Language Constraints Cause Repeats, Slower Speech, Fewer } \\
\text { Requests, and Controller to Reduce Clearance Items }\end{array}$ \\
\hline More & 23 & 48 & $\begin{array}{l}\text { Language Difficulties Cause U.S. Controllers to Treat } \\
\text { International Pilots Differently } \\
\text { More Time to Interpret, Clarify/Confirm Instructions and } \\
\text { Misunderstandings } \\
\text { Use Voice Inflection to Obtain Confirmation }\end{array}$ \\
\hline About the same & 8 & 17 & $\begin{array}{l}\text { Accents and Dialects Slow the Process and Impede } \\
\text { Understanding } \\
\text { Communication Protocol }\end{array}$ \\
\hline Less & 10 & 21 & $\begin{array}{l}\text { Fewer Transmissions } \\
\text { Less Conversation } \\
\text { Mandatory Communications, Few Requests }\end{array}$ \\
\hline Considerably less & 4 & 8 & \\
\hline
\end{tabular}

\section{More Time Spent Communicating Explanation}

Approximately $48 \%$ of the pilots who indicated more time was spent communicating discussed their response selection.

\section{Language Difficulties Cause U.S. Controllers to Treat Non-Native English-Speaking Pilots Differently}

It's been my experience that U.S. controllers treat international pilots differently if there is a significant level of difficulty trying to communicate. I've even heard controllers say something like, "Are there any English-speakers on your plane?" That's fairly direct.

\section{More Time to Interpret, Clarify/Confirm Instructions and Misunderstandings}

I have empathy for the South American carriers coming into Los Angeles because sometimes their pilots are pretty challenged with English. Controllers repeat the transmission two or three times because the pilots didn't get it the first time. On a typical international flight, pilots seem to take a little bit more time repeating instructions, clarifying instructions, and misunderstanding the language. It takes a little more time for them to hear and interpret it, just by the nature of the language. More time is needed just to say, "Say it again, please," that kind of thing.

I think understanding a detailed clearance is the biggest challenge for non-native English-speaking pilots. If they're having trouble, that's when I'Il hear controllers take them through there by baby steps, but only if there's a problem.

\section{Use Voice Inflection to Obtain Confirmation}

It's not only in the area of confirming clearances, but affirming what they heard because non-native English-speaking pilots are not certain that they got it right the first time. Sometimes they read it back with an inflection in the voice that seems to ask a question ${ }^{6}$ like, "What was that frequency?" as they read the frequency back. Quite often, it may take a couple [of exchanges] each way before the controller gets it to where they want it.

\section{About the Same Time Spent Communicating Explanation}

Of the eight pilots who selected this alternative, five explained their selection.

\section{Accents and Dialects Slow the Process and Impede Understanding}

It takes longer for the preciseness of the communication to be effected. That is, the essence of the communication process - from the time that a transmission is made to convey what we are trying to convey, to it being fully and precisely understood by the controller-has slowed down because of the language barrier, not the barrier from communication. The communication process is slowed when there is a difference in accent and dialect [among the pilots and controllers].

\section{Communication Protocol}

The chit-chat is now at a minimum between pilots and controllers, no matter what language they speak. Communications seldom exceed routine for both examples here. Sometimes it may be more if they are talking in their native language.

\section{Less Time Spent Communicating Explanation}

Approximately $60 \%$ of the pilots explained their selection.

\footnotetext{
${ }^{6}$ Questions generally end with a higher pitch at the end of an utterance and is recognized as questions by listeners regardless of background language and culture (Chen, A., 2005).
} 


\section{Fewer Transmissions and Less Said}

It seems to me that communication between English-to-English-speaking controllers and pilots is more frequent, relaxed, effective, and will have occasional pleasantries. But, the communications between non-native English-speaking pilots and native English-speaking controllers involve basic exchanges that are slower, more deliberate, and occur less often.

It's nothing but taking care of business. It's just not as easy for them to converse. The exchanges tend to be tense-unless the request to say again is used. When there is a question about a clearance, it probably requires three or four transmissions from each of them to get it absolutely clear.

\section{It's Less Conversation but More Time Clarifying}

Non-native English-speaking pilots eat up radio time asking, "Can you say that again? What was that? Can you tell me the last part one more time?" But to me, that's not much of a conversation-its clarification.

I think what happens-I'm positive of it -is that non-native English speakers limit their interactions because they don't speak the language nearly as well. So, they're not going to converse about all the nuances that we might talk about.

\section{Mandatory Communications, Few Requests}

I don't hear anything but mandatory communication between non-native English-speaking pilots and native English-speaking controllers. I hear standard requests and no additional requests for football scores or anything like that.

\section{Considerably Less Time Spent Communicating Explanation}

Of the four respondents who circled "Considerably less time," one said it was similar to the answer he gave to question 41 , just reversed. There was no further discussion.

\section{Do international native English-speaking controllers have to communicate differently with non-native English-speaking pilots than with native English- speaking pilots?}

For this question, pilots again were to consider communications they've heard over their radios in native English-speaking airspace (e.g., Hong Kong, U.K., U.S., New Zealand) when answering this question. An inspection of the pilots' discussions of this question indicated that all but one pilot seemed confused by the words have to as opposed to do they. Controllers do not have to communicate differently (no requirement), but they will. As shown in Table 7, 81\% of the pilots reported there were differences in how international non-native English-speaking controllers communicated based on the language spoken by the pilot, while 19\% reported no differences.

\section{Conditional Yes: International Native English- Speaking Controllers Have to Communicate Differently Explanation}

Among the pilots who gave a conditional "yes," two indicated that the controllers should communicate differently with non-native English-speaking pilots.

\section{Communication Practices}

Controllers should speak slowly, deliberately, and use ICAO standard [phraseology] to obtain more than just the call sign as a readback. If pilots just read back the call sign, did they really understand or not? Sometimes, the native English-speaking controller may have to go back and question something to make sure the pilot actually understood.

\section{Yes: International Native English-Speaking Controllers Have to Communicate Differently Explanation}

Thirty pilots reported differences occurred at least sometime in the communication process, of which $87 \%$ discussed their selection.

\section{More Phonetic Spelling, Standard Phraseology, and Repeats}

The native English-speaking controllers normally speak a little bit slower and give fewer instructions. Sometimes, they use simpler phrases and emphasize the more important words like heading or your speed.

Table 7. Pilots' Perceptions of How International Native English-Speaking Controllers Communicate With Non-Native English-Speaking Pilots and Native English-Speaking Pilots

\begin{tabular}{|l|c|l}
\hline \multicolumn{1}{|c|}{ Response } & $\begin{array}{c}\text { Number } \\
\text { of Pilots }\end{array}$ & \multicolumn{1}{c}{ Differences in Communication } \\
\hline Conditional Yes & 9 & Communication Practices \\
\hline Yes & 30 & $\begin{array}{l}\text { More Phonetic Spelling, Standard Phraseology, and Repeats } \\
\text { Slower Speech Backs Up All Communications } \\
\text { The Communication Depends on Controller Experience }\end{array}$ \\
\hline No & 9 & $\begin{array}{l}\text { Can Be Influenced by Experience and Language Skills } \\
\text { They Normally Use Standard Phraseology }\end{array}$ \\
\hline
\end{tabular}


Table 8. Changes in Pilot Situational Awareness Due to Changes in Language Understanding

\begin{tabular}{|l|c|l}
\hline \multicolumn{3}{|c}{ Ways Situational Awareness Is Affected by Changes in Language Understanding } \\
\hline \multicolumn{1}{|c|}{ Affect on Situational Awareness } & $\begin{array}{l}\text { Number } \\
\text { of Pilots }\end{array}$ & \multicolumn{1}{c}{ How Situational Awareness Is Affected } \\
\hline $\begin{array}{l}\text { Heightens Attention/Situational } \\
\text { Awareness/Increased Workload }\end{array}$ & 32 & $\begin{array}{l}\text { Auditory Attention Directed to Party-Line Communication } \\
\text { Auditory Attention Diverted to Locating the Aircraft } \\
\text { Situational Awareness Goes Up } \\
\text { Visual Attention Directed to TCAS } \\
\text { Workload Increases }\end{array}$ \\
\hline $\begin{array}{l}\text { Little or No Affect on Situational } \\
\text { Awareness }\end{array}$ & 8 & $\begin{array}{l}\text { Effectively Monitoring the Situation } \\
\text { It Becomes a Problem if Our Operations Are Affected }\end{array}$ \\
\hline $\begin{array}{l}\text { Misunderstandings Add Radio Time } \\
\text { and Preclude Required } \\
\text { Communication }\end{array}$ & 8 & $\begin{array}{l}\text { Adversely Affects Flight Deck Operations } \\
\text { Alters Radio Protocol } \\
\text { Develop Alternative Action Plan }\end{array}$ \\
\hline
\end{tabular}

Communication is more deliberate and formal (standard). They speak in short, concise sentences. They don't use local jargon; don't use slang; don't use anything off the wall. Sometimes they have to repeat.

\section{Slower Speech Backs Up All Communications}

Going into Kingston, a Jamaican controller speaks to a Cuban pilot in Jamaican English and the pilot responds in Spanish-accented English. The controllers slow down and speak in specific terms with a pronunciation that emphasizes every single syllableit's the only way they can make it work. From that standpoint, more time is spent with a slower speech pattern to communicate, and everything slows down.

\section{The Communication Depends on Controller Experience}

It's been my experience that a very seasoned controller can determine from the pilot's response to a clearance what they need to do to effectively make this communication happen. Seasoned controllers know that saying [the transmission] again and again is completely ineffective communication, and they don't have time to deal with that. So, they slow down and break it down to the most basic fundamentals so they don't eat up the rest of the airtime they need to manage the multiple airplanes that they have in the area. They understand that if they don't do that, the pilot's going to go back to "say again."

Interviewer: Do you have the same experience internationally as what you were just recounting here in North America?

Most of the time, the non-native English-speaking controllers have to be more deliberate with us because there's still that communication barrier, even though it's turned around. The controllers convey their communication more efficiently with [their own pilots]. German controllers can speak in German or English because the dialects and accents are similar between them and German pilots, so they can understand each other more effectively. The communications process slows down when I start to talk to them-they'll go, "huh?"
No: International Native English-Speaking Controllers Do Not Have to Communicate Differently

Of the nine respondents who indicated international native English-speaking controllers do not have to communicate differently with non-native English-speaking pilots, one said that controllers do not have to, but they will to communicate as best they can with pilots if the proficiency is not there.

\section{They Normally Use Standard Phraseology}

As long as controllers use standard phraseology there is no difference for usual communications, although it may be slower. Otherwise, controllers are generally more distinct, use standard ICAO, and try to keep communications simple. If something goes wrong, or there's weather, they'll probably have to spend more time communicating.

I feel empathetic for non-native English-speaking pilots coming into the U.S. because our controllers are used to working with us. Just because all pilots are expected to know English, doesn't mean they understand our slang. Sometimes, a controller will start with, "Yo, Air India," and I'm sure it just throws the pilots a huge "fur ball" right off the bat.

\section{Can Be Influenced by Experience and Language Skills}

It's not normally different, but it can be influenced by the experience and language skills of the pilot. And that's just the way it is. The pilots who do this on a routine basis know exactly what to expect, with absolutely no problems. But someone who's new at it is going to need more time. So, it varies with the individual and native country.

58. Describe how your situational awareness is affected when you suspect that non-native English-speaking pilots are experiencing difficulty understanding international English-speaking controllers.

The pilots' responses from the written and interview portions of the questionnaire are summarized in Table 8. Their contributions were organized into three themes. 
Approximately $67 \%$ of the pilots said it heightened their Attention, Situational Awareness, or Increased Workload. Another $17 \%$ said it had little or no affect on situational awareness, and the remaining $17 \%$ indicated misunderstandings add to radio time and preclude their required communication. Each of these themes contained issues that were discussed by the pilots during the interviews. The issues appear alphabetically according to theme.

\section{Heightens Attention/Situational Awareness Auditory Attention Directed to Party-Line Communication}

I'll pay particular attention in the communications, even though it doesn't necessarily pertain to my flight. There is a possibility of my involvement if I feel either the controller or the pilot didn't understand something or read back something that's not challenged. Otherwise, I want to minimize my presence on the radio to maximize the ability of the controller to resolve the issue and not step on their communications.

\section{Monitoring Radio Avoided a Near-Miss Event}

When I fly into Los Angeles, I am more cognizant of unexpected deviations from non-native Englishspeaking pilots. We have to pay closer attention. When I flew domestic, we had a near miss with [air carrier] because the pilot misinterpreted or misunderstood the clearance. Thank goodness, we were listening to what they were doing. They were on the wrong heading and went right in front of us. It was too close.

It has raised my worry-level when non-native English-speaking pilots do not understand and might conflict with my flight path. I regard it as another threat and listen intently to their clearances/requests. If I think that they don't understand, I try to find out what the problem is and avoid them.

\section{Auditory Attention Diverted to Locating the Aircraft}

As a crew, we listen more closely. It requires increased vigilance and attention to other conversations. I listen to their clearance to determine where they are-especially at what altitude-and if there is any possible impact on my flight. I do my best to stay out of the way. If I feel the air traffic controller's workload is increasing, as all that takes place also can affect us. I keep track of them to help keep my mission and airplane safe.

\section{Attention Directed Towards Eliminating Uncertainty}

My situational awareness goes down when the situation leads to doubt. I have to spend more time trying to figure out what he's saying, where he is, and what he's doing. I know what my airplane's doing, but I'm not sure where he is or where he's going. As I listen to their conversation, I'm not paying attention to what's going on in my own cockpit. So, my own $\mathrm{SA}$ is reduced as I eavesdrop on their conversation.

\section{Situational Awareness Goes $U_{p}$}

My situational awareness goes up when I hear a foreign pilot having problems with what he should be doing. I understand what's going on and know what the English-speaking controller wants him to do, so I'm really in tune with that situation.

\section{Visual Attention Directed to TCAS}

When I hear somebody having difficulty and language is an issue, my attention is heightened. When I start hearing problems, I want to know if they will be a threat to me or not. I am more alert, I pay more attention, and I am more proactive in looking around. I'm also watching him more closely on TCAS to see what he's trying to do. We might help resolve the situation or, alternately, get out of the way.

\section{Workload Increases}

It increases my workload due to the increased vigilance necessary to listen to both my clearances and their clearances as well.

\section{Little or No Affect on Situational Awareness Effectively Monitoring the Situation}

I'm clearly aware of what they are doing and where they are, but I don't think it's distracting from what's happening around me. For me, situational awareness is understanding all the events happening around me. I'm clearly aware of other aircraft, what they're doing, and where they're at; but their language problem is not affecting me.

\section{It Becomes a Problem if Our Operations Are Affected}

It makes little difference in my situational awareness because I can hear the other radios and they should be trying to speak English. TCAS is a valuable tool that I am already using, so situational awareness is not really the problem. The problem is getting cleared to get what you need or want out of a particular situation and the annoyance due to excess chatter on the radio. I'm not sure his problem is affecting me unless it starts impacting our operation-having to go hold somewhere.

\section{Misunderstandings Add Radio Time and Preclude Required Communication} Adversely Affect Flight Deck Operations

Misunderstandings tie up controller time and that takes time away from my flight's needs. I get boxed in and am not able to do what I need and want to do. The plan that I had developed is changed, and I have to adapt. That adds extra time discussing and verbalizing what's going on. It can even delay a clearance getting to us.

\section{Alters Radio Protocol}

I allow a lot more time before talking on the radio after the controller and non-native English-speaking 
Table 9. Effects of Language Understanding on Situational Awareness by Phase of Flight

\begin{tabular}{|r|l|}
\hline \multicolumn{1}{|c|}{ Rank } & \multicolumn{1}{c|}{ Phase of Flight } \\
\hline 1 & When preparing for final approach-from the final approach fix to the beginning of the landing flare. \\
\hline 2 & When preparing for descent-from cruise to either initial approach fix or VFR pattern entry. \\
\hline 3 & When in climb to cruise-from completion of initial climb to initial assigned cruise altitude. \\
\hline $3 \& 10_{b}$ & $\begin{array}{l}\text { When preparing for landing-transition from nose-low to nose-up attitude just before landing } \\
\text { touchdown. }\end{array}$ \\
\hline 4 & When taxiing-the aircraft is moving under its own power and terminates upon reaching the runway. \\
\hline 5 & When taxiing-the aircraft has exited the landing runway moving to the gate, ramp, or parking area. \\
\hline 7 & When in the en route phase under the control of en route centers. \\
\hline 10 & $\begin{array}{l}\text { When preparing for takeoff-aircraft is on the runway surface in takeoff position. } \\
\text { elevation or gear-up selection, whichever comes first. }\end{array}$ \\
\hline 11 & $\begin{array}{l}\text { When moving in the gate, ramp, or parking area - assisted by a tow vehicle (tug) moving to the } \\
\text { taxiway. }\end{array}$ \\
\hline $12 \mathrm{c}$ & $\begin{array}{l}\text { When preparing for departure-aircraft is stationary / When in the en route phase in international } \\
\text { airspace. }\end{array}$ \\
\hline
\end{tabular}

${ }_{\mathrm{b}}$ This phase of flight was ranked $3^{\text {rd }}$ and $10^{\text {th }}$ by the same number of pilots.

${ }_{c}$ Both of these phases of flight were equally ranked as having situational awareness least affected.

pilot have completed their radio call to make sure they don't need a repeat to understand their clearance. Typically, in the U.S., we'll snap right in after a guy releases his mic to make our call because it's hard to get in.

If there is a non-native English-speaking pilot having problems, misunderstanding, or anything, it will slow down everybody on the frequency. I try to make clear transmissions so nobody has to repeat. That gives more time for the controller and the non-native English-speaking pilot to be able to have multiple communications if they have to. Even if his not understanding has very little, if any, affect on my situational awareness, it's annoying due to the excess chatter on the radio.

\section{Develop Alternative Action Plan}

Situational awareness is not really the problem. The problem is getting cleared to get what you need or what you want out of a particular situation with a reduced flow of communication. I find myself strategizing-the controller might assign us a speed, but based upon how far we are on the approach or turning back around and such, we need to either get down or want to slow down so I won't get behind on the approach.

\section{Preparing for a Missed-Approach Event}

We had a non-native English-speaking pilot land ahead of us. The controller wanted him to make the high speed [exit onto a taxiway] and we were next in line to land. If he didn't make it, we would be real close to going around. So, knowing that these guys were ahead of us, and realizing that they didn't understand the communication, and having that situational awareness allowed us to be a little bit more prepared, if, in fact, we did have to go around, it was more in our thought process.

\section{Preparing for a Runway Incursion}

Another situation that I've seen is on the ground. I know that [non-U.S. flagship] is supposed to be stopping; he's in-between runways. If we're landing or getting ready to take off, I want to know he is stopped because it could greatly affect my operation. I know he's over there, and he's moving when he's not supposed to be moving; and he could cause a runway incursion, just like the one recently at LAX. ${ }^{7}$ There's a reason why that happened, and there's a miscommunication somewhere.

58a. When is your situation awareness most affected by language difficulties between non-native Englishspeakingpilots and English-speaking controllers? (Assign a "1" to the most affected, a "2" to the second most affected, etc. Assign a different number to each task.)

The pilots rank-ordered a list of 12 phases of flight that was derived from Phases of Flight Definitions and Usage Notes (CAST/ICAO Common Taxonomy Team, ${ }^{8}$ 2006). More than half indicated that their ranking was the same as those to question 44 in Report 4 (Prinzo et al., 2010c). Since five pilots did not provide rankings, those of the remaining 43 respondents are presented in Table 9. Only the two phases of flight most affected are presented.

\footnotetext{
When the interviews occurred, there had been eight runway incursions at Los Angeles International Airport.

8 Commercial Aviation Safety Team (CAST)/International Civil Aviation Organization (ICAO).
} 


\section{Ranking Philosophy}

I used the same logic - the level of the speed of the aircraft, the danger of the environment that I'm in, and then also the saturation of the radio traffic-affected how I organized these phases of flight from a higher to lower risk. My idea behind that was that if somebody's having trouble communicating, you're getting late clearances, it'll make you high and fast, steep, unprepared, ill-configured, that kind of thing.

As with Report 4 (Prinzo et al., 2010c), "When preparing for final approach" and "When preparing for descent" were ranked the highest by the pilots, but now "When preparing for final approach" was ranked highest. Two phases of flight were tied for Rank 3: "When in climb to cruise" and "When preparing for landing." Tied for being the least-affected phase of flight (Rank 12) were "When preparing for departure" and "When in the en route phase in international airspace." During these phases of flight, the pilot has limited or no contact with a controller.

\section{Rank 1}

When preparing for final approach-from the final approach fix to the beginning of the landing flare Closer to the Terrain and Other Airplanes

Language becomes an issue, not only for me but also for whatever everyone else is doing around us, as we get closer to the ground and runway. Any time we're in the terminal area on either arrival or departure, the closer to different airplanes we are is when we have to pay more attention. That's when I don't want to have language or communication problems.

\section{Increased Workload}

It's all about hearing. In the airplane, it's the most quiet as we start cruise, but in the descent phase, it's going to be louder and we have other things going on. My own situational awareness is most affected when my workload is high, i.e., during critical phases of flight. Well, it may delay a clearance for us and distractions break habit patterns, leading to mistakes.

\section{Rank 2}

\section{When preparing for descent-from cruise to either initial approach fix or VFR pattern entry}

I think that the greatest threat is when the airplane is in the air and when we're changing altitudes. Communication becomes time-critical because a clearance has got to happen. Any time a misunderstanding can lead to a conflict, or if there is a problem, it has to be resolved quickly-there is no time for messing around. I'm closest to other airplanes, and they could do the most harm to me. I can't stop the airplane and just wait.

\section{What do you do to compensate for any reduction in situational awareness?}

Forty-two pilots provided a list of 77 actions that were grouped together according to five themes. The six remaining pilots had nothing to offer. In fact, one pilot said there would be no reduction in situational awareness, one said he would do nothing, and four pilots did not respond.

Although some of the actions could appear in more than one theme, its final categorical membership was determined from its major focus or emphasis. For example, "plan the departures and arrivals well ahead" involves cognitive factors as well as navigation; closer examination led to it being placed into "Navigate" because its focus is on knowing the context in which a piloting task would occur.

Each theme is presented in Table 10 along with the number of times it appeared in the list of pilot actions. The first three themes relate to the basic skills typically drilled into student pilots by their instructors: Aviate, Communicate, Navigate. The other two relate to the operator: Cognitive Factors and Crew Resource Management.

\section{Basics \\ Aviate}

I focus on flying the airplane first. I start by scanning my instruments, looking to make sure that I'm verifying what I'm doing, where I' $m$ at, what they tell me. I am aware of the possibility of a reduction in situational awareness, so I do whatever is appropriate for my situation to not lose control of the task at hand. I might configure a bit early, slow down before the controller tells me to, that kind of thing.

If I recognize that my situational awareness has been reduced, I must resolve and terminate the cause. If I' $m$ flying the airplane, I turn on the autopilot to reduce my workload so I can glance down at charts. If on the ground, I might stop until I get it back.

\section{Communicate}

I listen more to communications. When I'm on the radio, I enunciate my words more clearly, and use deliberate phraseology. I use ICAO-standard communications. I confirm, clarify, and ask the controller questions because I don't assume anything.

\section{Navigate}

I plan for the departures and arrivals well ahead of time so that I know all of the restrictions and waypoints. If there's a problem, I will get my map out and know where the terrain is. Both TCAS and weather radar give me ideas about where the threats are and where safe areas might be. 
Table 10. What Pilots Do to Compensate for Reductions in Situational Awareness

\begin{tabular}{|c|l|}
\hline \multicolumn{1}{|c|}{ Theme } & \multicolumn{1}{|c|}{ Pilot Actions } \\
\hline Basics & \\
\hline Aviate (5) & $\begin{array}{l}\text { Aviate; Fly the airplane; Take appropriate action; Use the autopilot; Scan my } \\
\text { instruments }\end{array}$ \\
\hline Communicate (24) & $\begin{array}{l}\text { Communicate; Listen more intently (11); Speech delivery and content (5); } \\
\text { Question, confirm, verify with ATC (7) }\end{array}$ \\
\hline Navigate (11) & $\begin{array}{l}\text { Navigate; Map out; Plan departures and arrivals well ahead; TCAS (7); Use } \\
\text { aircraft equipment (weather radar) }\end{array}$ \\
\hline Operator & $\begin{array}{l}\text { Anticipate; Be more diligent, alert, deliberate; Identify the phrase that I am most } \\
\text { suspect of; Increase attention toward factors causing reduction in situational } \\
\text { awareness; Resolve/terminate cause; Increase attention; Concentration; Focus } \\
\text { vigilance (2); Keep distractions to a minimum; Ask for a repeat transmission; } \\
\text { Review (2); Predict; Analyze; Monitor; Slow the pace to the best of my ability (6) }\end{array}$ \\
\hline \multirow{2}{*}{$\begin{array}{l}\text { Crew Resource } \\
\text { Management (18) }\end{array}$} & $\begin{array}{l}\text { Use CRM; Part of any good preflight pilot brief is an acknowledgment that reduced } \\
\text { SA will happen for a variety of reasons, so good CRM is mandatory (6); Make } \\
\text { other cockpit crewmembers aware (2); Confirm, coordinate, involve, share } \\
\text { workload with other crewmembers (7); Query other pilots (2) }\end{array}$ \\
\hline
\end{tabular}

\section{Operator}

Cognitive Factors

I try to identify the phase that I'm most suspect of, focus harder, become more diligent, anticipate, pick up my level of alertness, and do more ground study. I am more deliberate in what I'm doing and concentrate more on the task at hand-not the stuff that doesn't really seem that necessary. I try to reduce my workload by asking for help. I make sure that what I'm hearing is what the controller's telling us. I query any question I have.

When I recognize I'm getting overloaded or going into a dicey situation, I know that I must slow the pace down and increase my attention to what's going on to maintain situational awareness. I'll increase my vigilance and keep distraction to a minimum. I still think at the same speed, but I become more deliberate with everything I do. I really start reviewing what's been going on and try to predict what's going to happen next.

\section{Crew Resource Management}

A part of any good preflight pilot briefing is an acknowledgment that reduced SA will happen for a variety of reasons. So, I have everybody in the loop at all times. If I'm tired or just woke up and coming out of the bunk still recovering from sleep inertia, ${ }^{9} \mathrm{I}$ make them aware. I get them involved through active listening and discussion because I want us all to agree on what we just heard before we make any changes to our flight path.

When I program the computer, I ask the other pilot to check what I have done so there are no surprises. When we're changing the mode control panel, everybody's involved in the action. One crewmember controls the airplane and the other backs up.

\footnotetext{
9 Sleep inertia is the grogginess a person experiences upon waking that can impair cognitive and psychomotor functioning.
}

\section{DISCUSSION}

In this section, we compare the results from Prinzo et al. Report 4 (2010c) with those in this report when the questions differ only in whether the non-native English speaker is the controller (ATC, Report 4) or pilot (FD, Report 6). This occurred for all but questions 43 and 44 in Report 4. The question pairs are 39-54, 39a-54a, 39b-54b, 40-55, 41-56, 42-57, 44a-58a, and 45-59. We attempt to describe the dynamics of international voice radio communications from the participants' responses and remarks.

Everyone develops expectancies as a result of life experiences. Some are event-based (e.g., some children learn that they go to bed after watching a particular program on television; as we approach the box office at a movie theatre, we expect to pay to watch the movie of our choice), while other expectations are time-based (e.g., bedtime is at 9:00 pm; arriving late to the movie theater results in missing some of the presentation, yet paying full price). These expectations allow all of us to live and act as rational beings in a somewhat unpredictable world.

In like manner, experienced pilots develop expectancies based on their flight experiences. They expect to hear messages at particular times during their flight, especially as they near an airport, sector boundary, or foreign airspace. During these times, they focus more of their attention towards actively listening for their flight identifier in preparation for receiving flight-related information. For example, the information could be from a radio operator, someone at their company, or an air traffic controller. If the communication is from air traffic control, the information typically involves instructions and clearances to a greater degree than advisories and reports (Prinzo, Hendrix, \& Hendrix, 2009). 


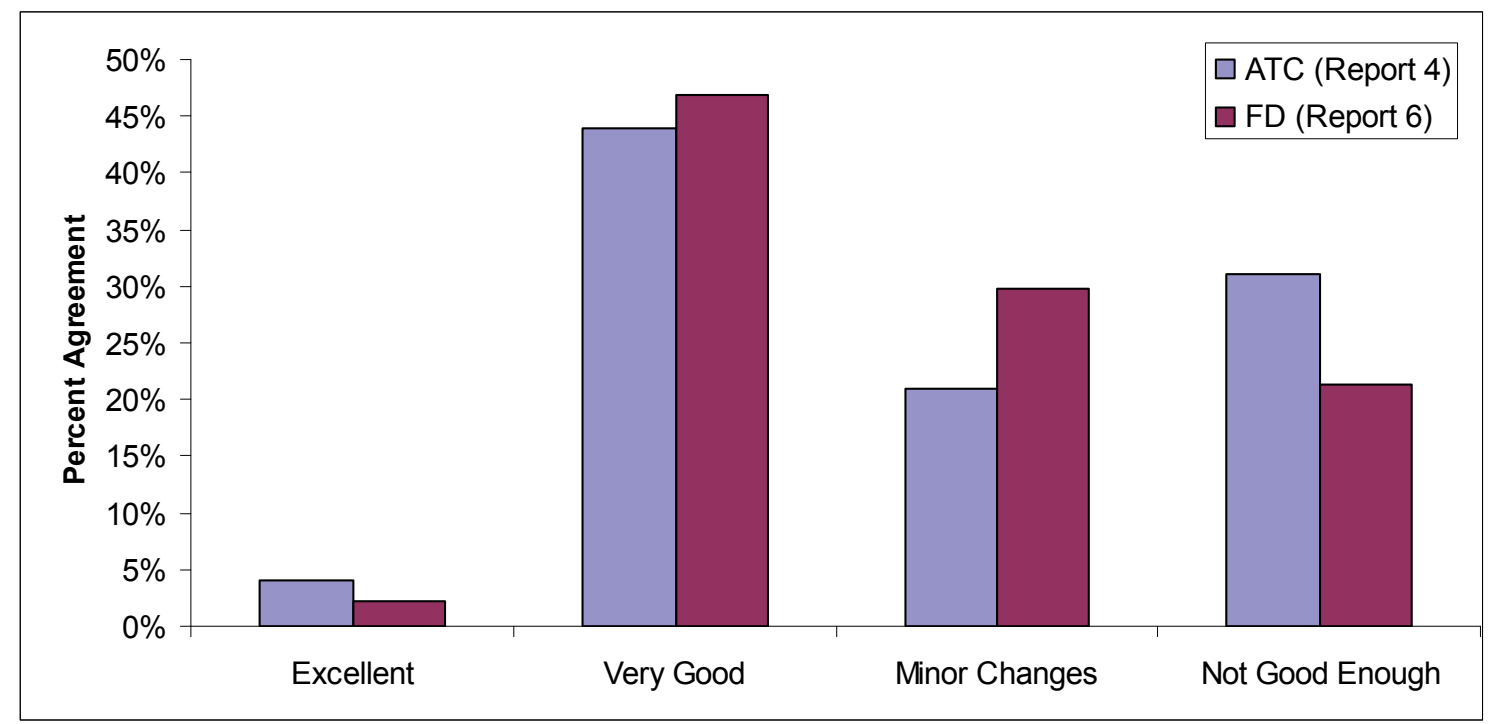

Figure 2. U.S. Pilots' Perceptions of Non-Native English Speakers' English Proficiency

Table 11. How Pilots Determine Non-Native English-Speakers' English Language Proficiency

\begin{tabular}{|c|c|c|}
\hline & \multicolumn{2}{|c|}{ Percentage of Instances $_{\mathbf{d}}$} \\
\hline ICAO Categories of Language Proficiency & Report 4 (controllers) & Report 6 (pilots) \\
\hline Comprehension & $6 \%$ & $28 \%$ \\
\hline Fluency & $25 \%$ & $28 \%$ \\
\hline Interaction & $7 \%$ & $12 \%$ \\
\hline Pronunciation & $37 \%$ & $22 \%$ \\
\hline Structure & $6 \%$ & $5 \%$ \\
\hline Vocabulary & $8 \%$ & $5 \%$ \\
\hline Other Categories of Language Proficiency & & \\
\hline Projected Confidence & $7 \%$ & \\
\hline Language-switching & $2 \%$ & \\
\hline
\end{tabular}

${ }_{\mathrm{d}}$ Percentages do not equal $100 \%$ due to rounding error

At other times, especially during oceanic operations, their attention may be distributed between aviating, navigating, and monitoring communications. While doing so, they update their situational awareness by listening for events that may affect the outcome of their flights (Report 4, Prinzo, Campbell, Hendrix \& Hendrix, 2010c). While monitoring the radio, they make judgments about other pilots' and controllers' knowledge, skills, and abilities; they "size them up."

Just as Prinzo et al. (e.g., Report 3, 2010b) point out that the pilots' perceptions of international controllers' English-language proficiency depends upon where they fly, with some non-native English-speaking controllers perceived as being more proficient than others, the same holds true for their perceptions of the English language proficiency of non-native English-speaking pilots.

\section{Determinants of the English-Language Proficiency of Non-Native English Speakers}

The U.S. pilots characterized the voice communications between non-native English-speaking controllers and native English-speaking pilots and those between native English-speaking controllers and non-native English-speaking pilots as basically the same, $\chi^{2}(3)=2.01$. That is, Figure 2 shows that $48 \%$ of them indicated voice communications were "very good" to "excellent," regardless of who in the pair was the native English speaker (i.e., the controller or the pilot). However, it also shows a tendency among the remaining pilots to report that "minor improvements" could be made between native English-speaking controllers and non-native Englishspeaking pilots, and that it was "not good enough" when non-native English-speaking controllers spoke with native English-speaking pilots.

The comparisons presented in Table 11 show that the U.S. pilots used the same descriptors to evaluate the English language proficiency of non-native English speakers. However, they use these descriptors differently to evaluate controllers and other pilots. Unlike Report 4, which showed a controller's Pronunciation occurred in $37 \%$ of their responses, in this report, Comprehension and Fluency each appeared in $28 \%$ of their responses as 


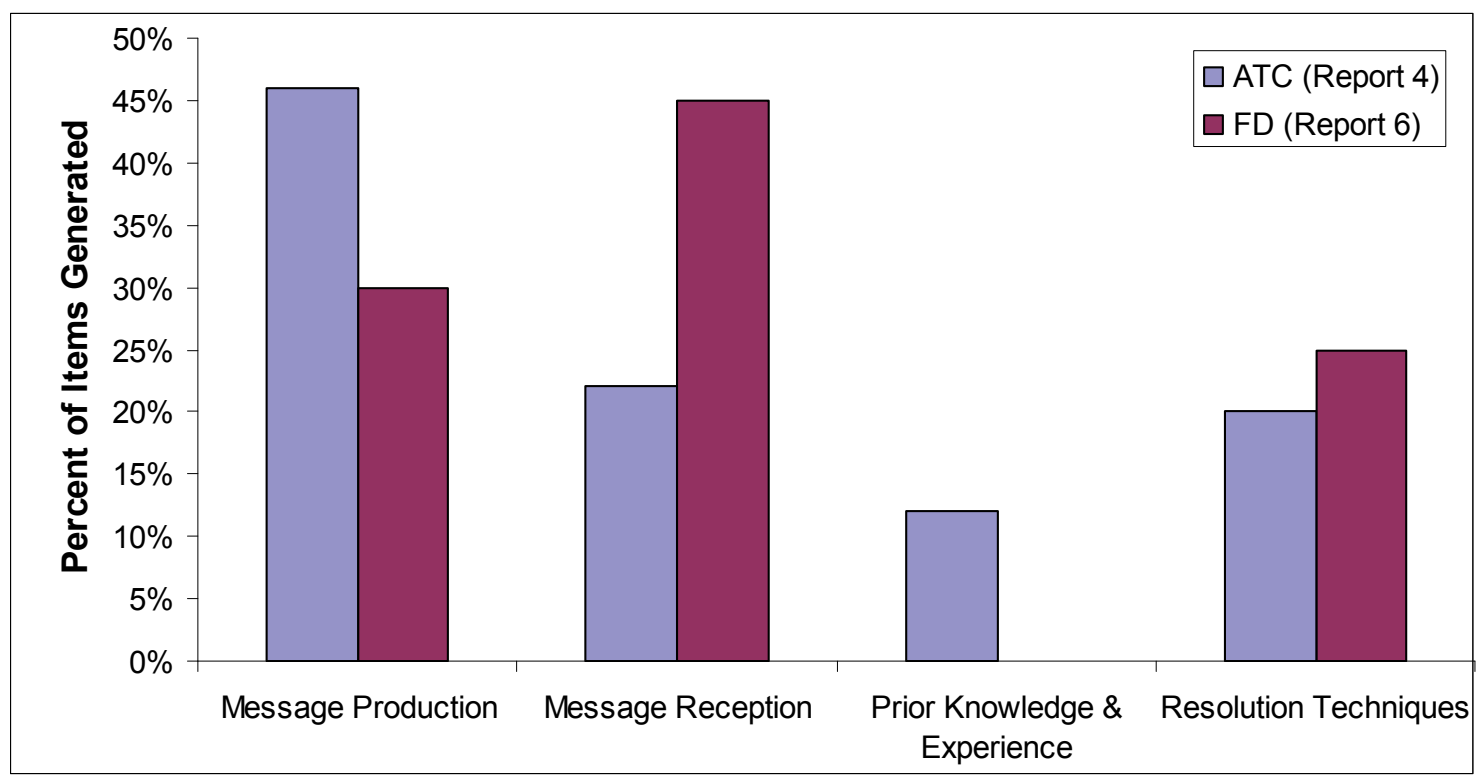

Figure 3. Tools Pilots Use When They Suspect Low Levels of English Language Proficiency

primary factors to determine a pilot's English language proficiency.

This makes intuitive sense when we consider the function that language serves aviators. Clearly, message reception is of primary importance-pilots must know what a controller said (decode) before they can successfully execute the message's contents. Thus, controllers and radio operators must be able to transmit intelligibly and communicate information effectively to minimize any language barriers that could compromise a pilot's mission: Knowing what was said precedes comprehending what to do.

Likewise, to accomplish what the controller wants requires that pilots fully comprehend the intent of the message and execute it properly. The controller and other pilots listen for the pilot to read back the to-be-performed actions fully and accurately prior to carrying them out. The presence of hesitation pauses (e.g., stretches of silence within phrasal or clausal boundaries) are indicative of speech planning (Ling, 2007) and filled pauses (e.g., uh's, um's) suggest performance problems (Clark \& Tree, 2002); both are indicators of a speaker's fluency in a given language.

\section{Actions U.S. Pilots Take When Communication Appears Problematic}

The purpose of questions $54 \mathrm{~b}$ and $39 \mathrm{~b}$ was to learn what U.S. pilots do when they suspect non-native Englishspeaking pilots and controllers have difficulty understanding each other. As shown in Figure 3, the action pilots took was dependent upon the speaker-if a controller, Message Production; if another pilot, Message Reception.

Among the U.S. pilots, simply said, the controller's proficiency in the English language matters. If they perceived controllers as having reduced English language proficiency skills they would (1) speak slowly and clearly, (2) spell out the names of fixes, waypoints, and intersections, and (3) only use ICAO phrases, vocabulary, and terms when they produced a message. Since decoding precedes comprehension when listening, it stands to reason that the pilots would want to maximize the likelihood that any difficulty in communication would reside with the controller and not themselves. The only aspect of communication over which they have some control is with their own English language production skills.

In contrast, if U.S. pilots perceived non-native English-speaking pilots as having similar problems with the English language as controllers, they would listen more attentively to communications between the pilot who was less proficient in English and the controller. They also said they would confer with the other pilots on the flight deck about what was said.

U.S. pilots know they have no authority over what other pilots and controllers say to one another. However, by listening in on the party line, they develop resolution techniques if they believe potentially unsafe situations or events are unfolding and have concerns about how their flights might be affected. Furthermore, if there was any question as to what was said (words) or heard (actions), U.S. pilots said they would ask for clarification, verification, and confirmation to remove any doubts or uncertainties about what the controller said or what the pilot was going to do. If necessary, they would vacate the vicinity to preserve the safety of their passengers.

\section{U.S. Pilots' Perceptions of Operational Communication: Native and Foreign Language Pairings}

Figure 4 displays which reports related to the pilots' perceptions of the communications between speakers of the same language (e.g., English-English, Spanish-Spanish) and different languages (e.g., English-Mandarin Chinese, 


\begin{tabular}{|l|l|l|}
\hline Speaker & \multicolumn{2}{|c|}{ Language Pair } \\
\hline Native English & $\begin{array}{l}\text { Both Speak a Native English Language } \\
\text { (R6) }\end{array}$ & $\begin{array}{l}\text { Pilot Speaks a Native English Language \& } \\
\text { Controller Speaks a Non-Native English } \\
\text { Language (R4) }\end{array}$ \\
\hline Non-Native English & $\begin{array}{l}\text { Pilot Speaks a Non-Native English } \\
\text { Language \& Controller Speaks a Native } \\
\text { English Language (R6) }\end{array}$ & $\begin{array}{l}\text { Both Speak the Same Non-Native English } \\
\text { Language (R4) }\end{array}$ \\
\hline
\end{tabular}

Figure 4. U.S. Pilots' Perceptions of Communications of the Same and Different Language Pairs

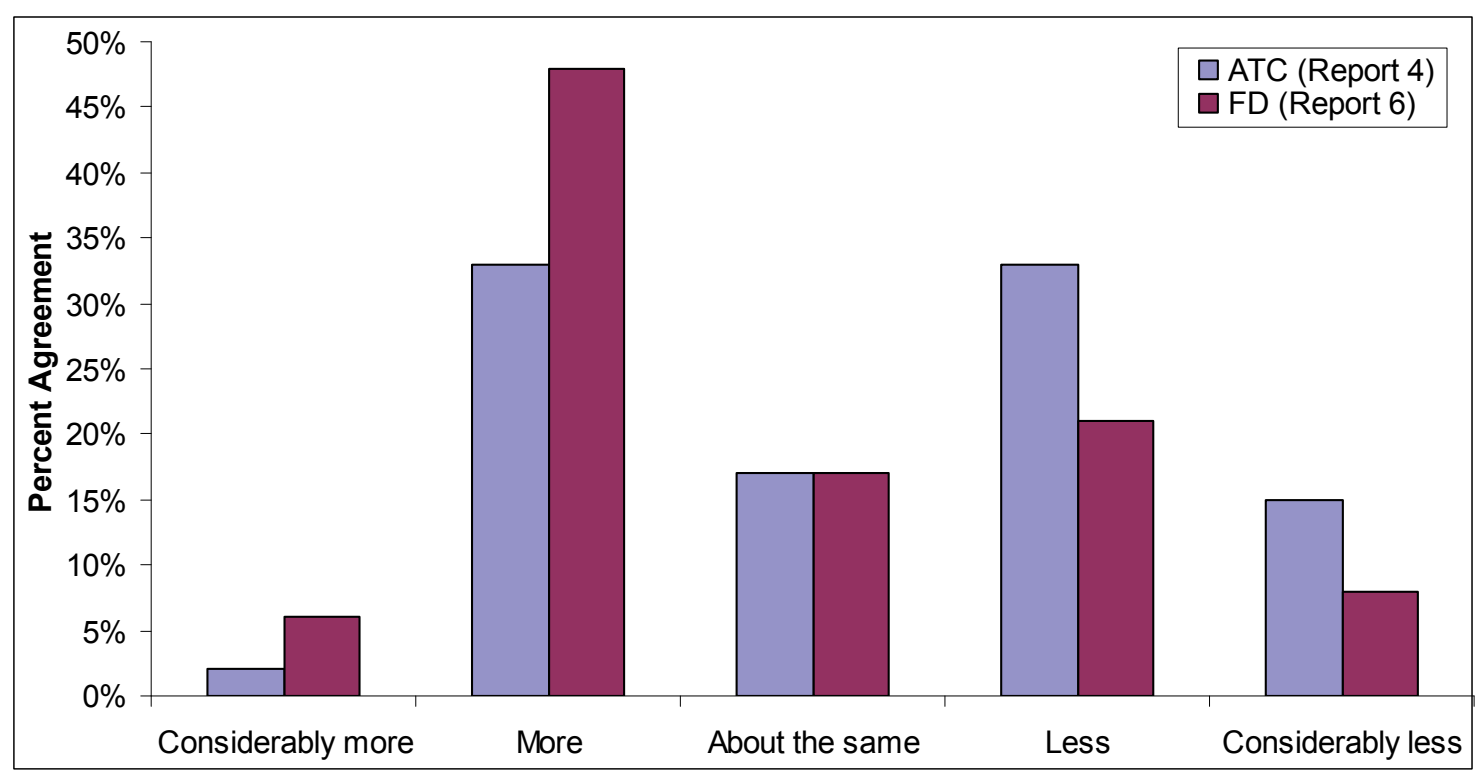

Figure 5. Relationship Between Language Pairings and Time on Frequency

Russian-Italian). Intuitively, U.S. pilots should perceive no real differences in the communications occurring between pilots and controllers who are native speakers of English (Report 6) or speak the same non-native English language (Report 4).

The results from questions 55 and 56 (Report 6) were combined, as were questions 40 and 41 (Report 4) because they asked about the pattern and duration of communications between same and different language pairs of speakers. When the language of the controller and pilot match (top left and bottom right cells), they share a common thread to the features of their language (e.g., auditory and articulatory, lexical, semantic, pragmatic). Although differences may exist in the pronunciation of individual words, these differences are fairly easy to decode. For example, in the U.S., the pronunciation of the word "time" by a person from the East is said with a hard "i" vowel sound. But, a person from the South may pronounce it as "Tom," causing the " $i$ " to be spoken as "ah" (Gordon, 2005; MacNeil \& Cran, 2005).

\section{A Description of Same-Language Pilot/Controller Communications}

The temporal relationship between language pairs appears in Figure 5. It shows that the U.S. pilots' perceived speech production as easier and taking less time to communicate when both the controller and pilot are native English speakers (top left cell). As a team, they may use more plain (conversational) English, slang, and local jargon-especially when their communications do not fit the prescribed phraseology. Finally, the U.S. pilots indicated that U.S. controllers expect them to comply with a long series of instructions given as a single transmission.

The communication exchanges between controllers and pilots who speak the same non-native English language (see Figure 4, bottom-right cell) seem to be similar in the speed of communication and ease of understanding of those made by native English-speaking controllers and pilots. Among the U.S. pilots who understood the nonnative English languages, they reported that the controllers and pilots used local jargon and extended greetings to one another. From the tone of their interactions, it appeared as if the pair was relaxed, casual, and familiar with one another.

\section{A Description of Different-Language Pilot/ Controller Communications}

When a mismatch occurs between the languages of the pilot and controller (see Figure 4, top-right and bottomleft cells), differences exist in some of each language's inherent features (primarily in their surface characteristics) that could alter communications. It was uncertain 
whether the pilots would report the communications between non-native English-speaking pilots and native English-speaking controllers (Report 6) as being comparable to those between native English-speaking pilots and non-native English-speaking controllers (Report 4).

Furthermore, Figure 5 also shows that the U.S. pilots stated that it took non-native English-speaking controllers more time to switch from their native languages back to English and longer to convert words normally spoken in their language into English (Figure 4 top-right cell). Generally, when speaking, non-native English-speaking controllers slow down and, depending on their English skills, may pronounce words differently than expected by the U.S. pilots. When foreign pilots were on the radio, non-native English-speaking controllers also seemed to maintain greater radio discipline.

When U.S. pilots communicate with non-native English speaking controllers (Figure 4, top-right cell), they keep nonstandard or non-required communications to an absolute minimum. They choose their words carefully-avoiding slang, words, and phrases that could be misinterpreted by controllers. They also try to speak slower and clearer to make communications effective. Furthermore, they are advised by their respective companies against substituting "oh" for "zero" or "point" for "decimal" and words not contained in the ICAO standard.

The U.S. pilots reported that, in their experience, the pattern of communications between native Englishspeaking controllers and non-native English-speaking pilots is structured to build time into the traffic flow (Figure 4, bottom-left cell). Seasoned controllers know the communications process is more time consuming and slower with less proficient speakers, so they make their communications deliberate to facilitate pilot understanding. Ironically, this speeds up the operation. Speaking slower, sending shorter messages (one instruction or clearance), and using standard phraseology affords less proficient speakers with added time for translation to occur. In this way, controllers avoid having to repeat a message three or four times.

Furthermore, the pilots reported that non-native English-speaking pilots are slower in their readbacks, ask more questions, and make more requests for repeats-especially if given a lengthy or complex message. Rarely do they use any slang when speaking English. Voice tape analysis (Prinzo et al., 2009) of non-native English-speaking pilots communicating with U.S. enroute controllers confirm the U.S. pilots perceptions-not only did non-native English-speaking pilots spend more time communicating, they also exchanged more transmissions and had more communication problems in their transactions. If faced with an unexpected situation, an off-nominal event, or a change in the scripted communications, then language proficiency can become a safety issue.
Their perceptions also are consistent with a content analysis performed by Tiewtrakul and Fletcher ${ }^{10}(2010)$. They examined the communication between Thai controllers and local Thai pilots, native English-speaking pilots, and non-native English-speaking pilots. In their study, the controllers' accent influenced their English pronunciation to the point that foreign pilots were at a disadvantage understanding clearances, as evidenced by differences in the number of readback errors, requests for repeats, and failures to respond.

\section{Compensating for Reductions in Situational Awareness}

As with Report 4, "When preparing for final approach" and "When preparing for descent" were ranked the highest by the pilots, but now "When preparing for final approach" was ranked higher. The difference in their ordering dealt with the potential threat level they inferred from actively listening to the communications between a non-native English-speaking pilot and English-speaking controller. Doing so assisted them in projecting the likelihood of a near-miss, runway incursion, or missed approach.

Understandably, with improved traffic surveillance and detection, the separation minima in oceanic, en route, terminal and airport environments decrease. The closer a pilot is in proximity to another aircraft, the less time available to get out of the way of that aircraft, should their paths conflict. Pilots who are proficient in English need less time to decode, comprehend, and execute a control instruction or clearance than pilots who are less proficient. Thus, the differences in the pilots' rankings take translation and language proficiency into consideration. When they need more time to resolve a language problem, they want extra time for just that purpose. They do not want to "get behind the airplane." Thus, the top-of-descent becomes more critical for them because they have to deal with language barriers in addition to having more to do in preparation for final approach.

But, when they know the language well, comprehension appears to be automatic. Time constraints are fully realized on final approach (separation can be as little as $3 \mathrm{~nm}$ ) and offers pilots little cushion for decision-making or conferring with other crewmembers about differing possibilities when faced with immediate action. Now, final approach becomes the most critical phase of flight because they know that there is limited time to maneuver to avoid a conflict.

As noted throughout the report, being able to communicate in one's native language is advantageous to both the pilot and controller pairing: It is effective, efficient, and easy to do. When U.S. pilots communicate with native-English speaking controllers, the direct influence of a language barrier is non-existent and linguistic processes

\footnotetext{
${ }^{10}$ Originally an unpublished Master's thesis (Sep 2007) entitled, "Analysis of Approach Controller-Pilot Communication" at Cranfield University, Human Factors Department, School of Engineering.
} 
are performed automatically and effortlessly. Flight operations place minimal demands on their cognitive abilities.

This is not the case when the languages of the pilot and controller differ. Now, U.S. pilots must anticipate possibilities and develop alternatives that may distract them from their primary tasks. Let's take the hypothetical situation of a non-native English-speaking pilot and a native English-speaking controller experiencing difficulties communicating with one another. The controller is faced with having to alter the arrival of one of two aircraft-one native English language registry and the other not. Both aircraft are of the same type and series (e.g., 767-400ER), so performance and restrictions are not factors. Of these two aircraft, which one does the controller allow to proceed on course and which one is instructed to go-around, put into a hold, or diverted? It is no surprise that during these times U.S. pilots develop contingency plans-just in case.

When faced with a possible reduction in situational awareness (brought on by language problems), the U.S. pilots said they may have to revert to the basics of their flight instruction: Aviate first, navigate second, and communicate third. They may configure their plane a little early or slow down in anticipation (based on their preflight preparation). Also, to help with communications, they may continue using ICAO standard phraseology as a way to help the less proficient pilot who is operating in an English-speaking environment. They are focused, deliberate in language production, and use crew resource management.

In summary, being able to communicate effectively is the goal of language, regardless of how it is conveyed. When pilots and controllers speak different native languages, traffic flow slows down as operational communications become more deliberate and effortful. Both will carefully select their word choices, say them slower, and attempt to pronounce them correctly. They know it takes more time to translate from a foreign language into their native language and back again. Translation is not a factor when the pilot and controller share the same native language. Other pilots on the party line listen for the participants' mutual understanding. In the meantime, they may develop a working contingency plan should language become a barrier to otherwise seemingly effortless communication.

Pilots and controllers deal with the same frustrations due to lack of a global standard for aviation English and ATC procedures. The presence of off-nominal events, unexpected situations, and unforeseen circumstances make language barriers visible to the user-community. We have identified seven issues pilots experience, regardless of their language of origin:

1. All speakers need to slow down their speech rate and speak with clarity.

2. Controllers need to develop greater patience with non-native English-speaking pilots.
3. ATC instructions can be incongruent with pilot expectations.

4. Lack of familiarity with a country's procedures and phraseology slows down the system.

5. Countries that do not adhere to ICAO standard phraseology and terminology contribute to the communication problems that occur between their controllers and foreign pilots.

6. The failure to communicate can distract other pilots in the area from performing essential tasks.

7. The failure to develop a common ground of understanding is a continuing risk to flight safety.

We offer the following five recommendations that were derived from the information provided by the pilots during the interviews.

\section{Recommendations}

1. Research is needed to determine the optimal speech rate for ATC messages. If the operator cannot adjust the speaking rate of an incoming message, then an agreed-upon rate of speech must be developed for delivery to less proficient non-native English speakers.

2. ATC messages must be delivered using standard ICAO terms and phraseology. The air traffic controller, Datalink communications system, and pilot must be in agreement as to what messages are in the data dictionary and how each message will be used to convey instructions, clearances, reports, and requests.

3. Graphic and text representations of taxi clearances, route clearances, and route modifications should be made available to pilots on the flight deck as standalone messages.

4. Research is needed to identify how controllers communicate nonstandard situations (e.g., maneuvering around thunderstorms, traffic conflicts, delays). New phraseology may be needed in lieu of the work-around practices of Common English currently in use. Pilots unfamiliar with the local jargon and slang are at a disadvantage and may misinterpret these conversations. For example, "You're following an MD eighty but he's gotta slow up uh the train's starting to slow down ahead" may not be meaningful to a pilot unfamiliar with local jargon.

5. The absence of party-line communications can distract pilots prior to takeoff and landing while they attempt to discern the intentions (and potential threat) of other pilots (especially those less proficient in English). Research is needed to determine whether providing pilots with alternative representations of party-line information provides the same or better situational awareness as exists in the current aviation environment and its affect on aviation safety. 


\section{REFERENCES}

CAST/ICAO Common Taxonomy Team. (Feb. 2006). Phases of flight definitions and usage notes version 1.0.1. Retrieved from intlaviationstandards. org/Documents/PhaseofFlightDefinitions.pdf. Accessed 04 Nov 2010.

Chen, A. (2005). Universal and language-specific perception of paralinguistic intonational meaning. Netherlands Graduate School of Linguistics: LOT Publications. ISBN90-76864-69-1.

Clark, H. \& Tree, J. (2002). Using uh and um in spontaneous speaking. Cognition, 84, 73-111.

Gordon, M. (2005). Language change vowel shifting. Do you speak American? PBS Broadcast pbs.org/speak/ ahead/change/changin/.

Hayes, A. F. \& Krippendorff, K. (2007). Answering the call for a standard reliability measure for coding data. Communication Methods and Measures 1, 77-89.

International Civil Aviation Organization (2004). Manual on the implementation of ICAO Language Proficiency Requirements. Doc 9835/AN453. Montreal, Quebec, Canada: Author.

Ling, H. (2007). Long pauses in Chinese EFL learners' spontaneous speech. Interlingüistica, 17, 606-616.

MacNeil, R. \& Cran, W. (2005). Do you speak American? New York, NY: Doubleday.

Prinzo, O.V. \& Campbell, A. (2008). U.S. airline transport pilot international flight language experiences, report 1: Background information, general/pre-flight preparation and generallair traffic control (ATC) procedures. (Report no. DOT/FAA/AM-08/18). Washington, DC: Federal Aviation Administration.
Prinzo, O. V., Hendrix, A. M., \& Hendrix, R. (2009). The outcome of ATC message length and complexity on en route pilot readback performance. (Report no. DOT/FAA/AM-09/2). Washington, DC: Federal Aviation Administration.

Prinzo, O. V., Campbell, A., Hendrix, A. M., \& Hendrix, R. (2010a). U.S. airline transportpilotinternational flight language experiences, report 2: Word meanings and pronunciation. (Report no. DOT/FAA/ AM-10/7). Washington, DC: Federal Aviation Administration.

Prinzo, O. V., Campbell, A., Hendrix, A. M., \& Hendrix, R. (2010b). U.S. airline transport pilot international flight language experiences, report 3: Language experiences in non-native English-speaking airspacelairports. (Report no. DOT/FAA/AM-10/9). Washington, DC: Federal Aviation Administration.

Prinzo, O. V., Campbell, A., Hendrix, A. M., \& Hendrix, R. (2010c). U.S. airline transportpilot international flight language experiences, report 4: Non-native English-speaking controllers communicating with native English-speaking pilots. (Report no. DOT/ RAA/AM-10/12). Washington, DC: Federal Aviation Administration.

Prinzo, O. V., Campbell, A., Hendrix, A. M., \& Hendrix, R. (2010d). U.S. airline transport pilot international flight language experiences, report 5: Language experiences in native English-speaking airspacelairports. (Report no. DOT/FAA/AM-10/18). Washington, DC: Federal Aviation Administration.

Tiewtrakul, T., \& Fletcher, S.R. (2010). The challenge of regional accents for aviation English language proficiency standards: A study of difficulties in understanding in air traffic control-pilot communications. Ergonomics 53, 229-239. 
